\title{
Application of Industry 4.0 in the Procurement Processes of Supply Chains: A Systematic Literature Review
}

\author{
Niloofar Jahani ${ }^{1}$ (D), Arash Sepehri ${ }^{1}$, Hadi Rezaei Vandchali ${ }^{2}$ and Erfan Babaee Tirkolaee ${ }^{3, *(D)}$ \\ 1 School of Industrial Engineering, Iran University of Science and Technology, Tehran 13114-16846, Iran; \\ jahani.niloofar1994@gmail.com (N.J.); arashsepehri72@gmail.com (A.S.) \\ 2 Department of Maritime and Logistics Management, University of Tasmania, \\ Launceston, TAS 7005, Australia; hadi.rezaei@utas.edu.au \\ 3 Department of Industrial Engineering, Istinye University, Istanbul 34010, Turkey \\ * Correspondence: erfan.babaee@istinye.edu.tr
}

Citation: Jahani, N.; Sepehri, A.; Vandchali, H.R.; Tirkolaee, E.B. Application of Industry 4.0 in the Procurement Processes of Supply Chains: A Systematic Literature Review. Sustainability 2021, 13, 7520. https://doi.org/10.3390/su13147520

Academic Editor: Tamás Bányai

Received: 8 June 2021

Accepted: 1 July 2021

Published: 6 July 2021

Publisher's Note: MDPI stays neutral with regard to jurisdictional claims in published maps and institutional affiliations.

Copyright: (c) 2021 by the authors. Licensee MDPI, Basel, Switzerland. This article is an open access article distributed under the terms and conditions of the Creative Commons Attribution (CC BY) license (https:// creativecommons.org/licenses/by/ $4.0 /)$.

\begin{abstract}
The fourth industrial revolution has significantly changed the traditional way of managing supply chains. The applications of Industry 4.0 (I4.0) technologies such as the Internet of Things (IoT) and Artificial Intelligence (AI) in different processes of supply chains have assisted companies to improve their performance. Procurement can be considered a critical process in supply chain management since it can provide novel opportunities for supply chains to improve their efficiency and effectiveness. However, I4.0 applications can be costly and may not be reasonably affordable. Therefore, the benefits of implementing these technologies should be clarified for procurement managers before investing in the digitalization of the procurement process. Despite the importance of this issue, few papers have attempted to address the effects of I4.0 technologies and smart systems in procurement. To fill this gap, a Systematic Literature Review (SLR) on the applications of I4.0 technologies in procurement has been used in this study. By reviewing 70 papers through appropriate keywords, a conceptual framework is developed to classify different value propositions provided by the different applications of I4.0 technologies in procurement processes. Results reveal nine value propositions that can provide a better understanding for the procurement department to analyze the benefits of implementing the related I4.0 technologies in different activities. Finally, findings and future study opportunities are concluded.
\end{abstract}

Keywords: industry 4.0; procurement process; value proposition; systematic literature review; supply chain; sustainable development

\section{Introduction}

Over the past decades, the traditional functions of the supply chain have evolved into broader and more modernized strategic approaches due to the emerging technologies [1]. In other words, with the manifestation of the industrial revolution, a new area of digitalization has emerged, and the concept of smart manufacturing has been revealed. As a result, notions such as smart factory, smart logistics, smart product, smart contract, etc., and in summary, "smart things" are developed, and companies have used digital technologies to transform their supply chain (SC) operating model [2]. These technological improvements are part of the Fourth Industrial Revolution named Industry 4.0 (I4.0). I4.0 which has been used in various processes of SC, portrays a connection of smart and physical assets, like smart products and machines that operate autonomously and create self-coordinating systems [2]. To illustrate more, the term "I4.0" which was first represented in Germany in 2011, deals with the connection of all parts of manufacturing elements and integrated data chains through the Internet and has a significant effect on the swift competition between suppliers, manufacturer, and retailer [3-5]. One of the most significant processes in the SC which directly affects its performance is the strategic management of procurement operations [6]. Procurement is defined as any buying process including purchasing, leasing, renting, or 
otherwise acquiring supplies, services, or construction from external suppliers $[3,7,8]$. This concept contains all management responsibilities that procurement managers should follow including identifying, sourcing, accessing, and managing resources outside the company and needed to fulfill the strategic objectives to help organizations hold significant business value and impact profit $[3,7,8]$. Therefore, procurement can be considered a critical part of a supply chain which highlights the importance of continuous improvements in the procurement department. Recently, using I4.0 applications in procurement is expanded, which facilitated the procedure of purchasing as a useful means. "Procurement $4.0^{\text {" }}$ is a component of I4.0, which introduces to connect all SC upstream partners, and enables dynamic and quick cooperation and coordination beyond organizational frontiers [3]. Some examples of I4.0 technologies that can help procurement managers to deal with purchasing challenges are the Internet of Things (IoT), Cyber-Physical Systems (CPS), Cloud Computing (CC), Big Data Analytics (BDA), Robotics, Blockchain, Artificial Intelligence (AI), Smart Manufacturing, ERP systems, simulation, Internet, procure-to-pay systems, Contract Management Systems (CMS), third-party providers, etc. [3,8-12]. By way of illustration, AI can help in analyzing different patterns leading to a better understanding of certain behaviors in suppliers which can help procurement managers to identify appropriate prospective suppliers [13]. Another example can be related to Blockchain technology which can incorporate characteristics of a decentralized "trustless" database and allows for globalscale transactions and process disintermediation which ultimately can help procurement managers access and track transaction archives for suppliers [14]. Having these kinds of examples can illustrate how significant it is to implement I4.0 technologies to reinforce the purchasing process.

Despite the importance of using I4.0 technologies in procurement, it can be challenging for companies to invest in these technologies. The main significant problem is related to the cost of the implementation process of I4.0 technologies. AI-based approaches, as an example, can be seen as a high-cost performing and maintaining technology that can cost up to $\$ 250,000$ per hour [15]. This has been one of the main reasons why companies are still in doubt about implementing I4.0 technologies that whether these expensive applications help them to meet their expectation of the required benefits. Thus, providing clear values that the I4.0 application might propose brightens the competencies of performing I4.0 for companies. To put it another way, companies need to know how the investment in technology can bring the required value to overcome new challenges they may face. Many papers work on the application of I4.0 in procurement (P4.0) in the related literature. However, there is still a strong need to develop a comprehensive framework of how I4.0 can bring value to the procurement department. To fill this gap, this paper will review the existing papers to identify these values via the systematic literature review method (SLR). By developing a conceptual framework, this paper presents what sorts of values the application of I4.0 can bring to the procurement, helping managers better understand how their investment can pay off. To the best of our knowledge, this paper is the first attempt to bring this matter to attention, and investigate the value of I4.0 technologies in procurement.

In this regard, first, a survey in the literature and a systematic approach is proposed in Section 2. Then, in Section 3, the discussion and findings of previous works are reviewed. Section 4 is the main section in which procurement values provided by different I4.0 technologies are diagnosed, and related technologies that can help reduce the challenges are presented. The final section contains the discussion, conclusion, limitations, and recommended directions for future studies.

\section{Systematic Literature Review}

A Systematic Literature Review (SLR) approach is applied to this study for collecting, filtering, and analyzing the related papers. The SLR is carried out by (1) defining appropriate keywords for searching, (2) identifying relevant papers, and (3) analyzing the extracted papers. A large number of papers have worked on the topic of procurement and I4.0 technologies separately [16-21], however, 70 papers mainly concentrate on the 
contribution of both subjects simultaneously which are selected from Scholar, Scopus, and Web of Science databases. Selected papers are mainly from renowned publications such as Elsevier, Springer, Taylor and Francis, Emerald, etc. The seven steps structure in Figure 1 is developed for further elaboration [22]. Besides, the significance of developing a systematic literature review has been addressed by Paul et al. [23] and Paul and Criado [24]. One of the important goals of a systematic literature review is to identify key research gaps based on what constructs, theories, and methods are utilized in different settings and in what contexts studies have been carried out. Accordingly, authors of a classic review article provide directions for future research concerning new and novel ideas, theories, measures, methods, and novel research questions. A very well-crafted literature review article has the potential to serve as a platform for future research because such an article explicitly synthesizes current knowledge, identifies research gaps, and suggests exciting new directions for future research in a given field of research, regarding Methodology, Constructs/Variables, Theory, and Contexts.

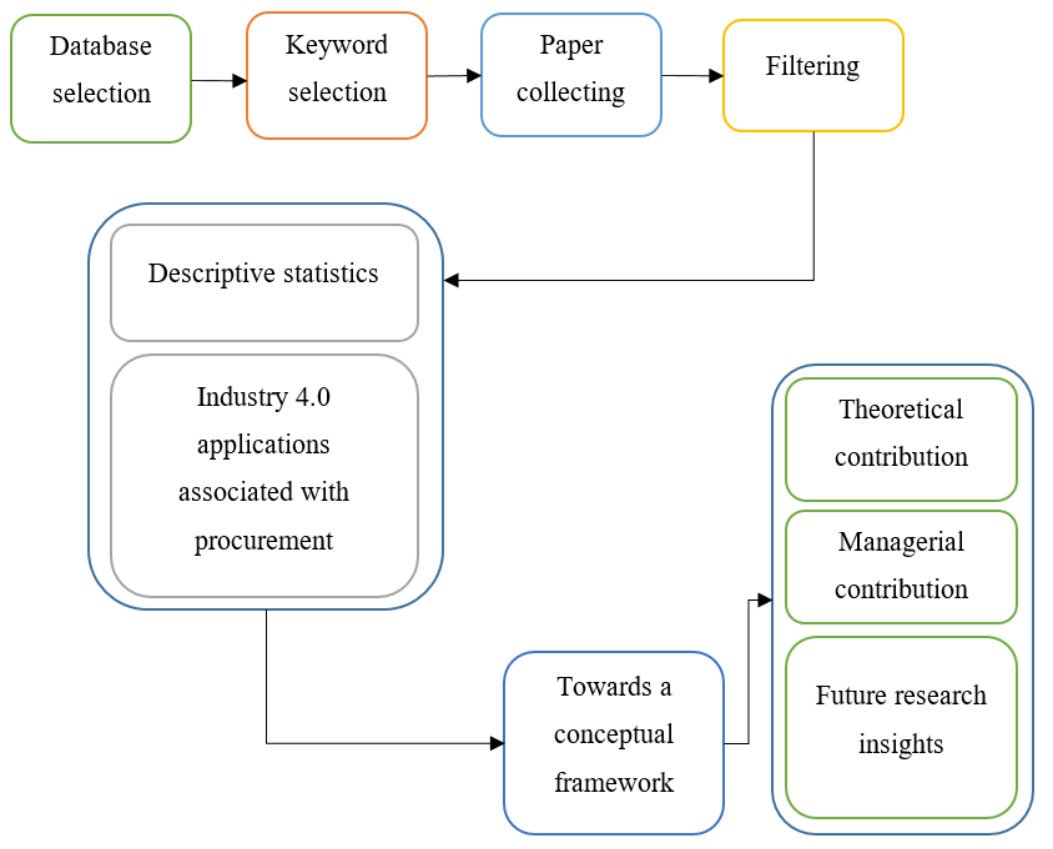

Figure 1. Review progress for our elaboration (Source: Author).

The first step is to choose the relevant literature through Scholar, Scopus, and Web of Science. In the second step, we select the keywords related to the topic which are classified into two discrete categories:

Category 1: Industry 4.0, CPSs, Cloud systems, BDA, Simulation, AI, IoT, Robotics, Blockchain, Smart manufacturing.

Category 2: Procurement, Purchasing, Supply, Supplier selection, Supplier evaluation, Order allocation, Resource allocation, Procurement 4.0, Public procurement, Contract management.

In the third step, a combination of keywords from the above categories is applied to collect related papers. Then, in the fourth step, duplicate papers from different databases are removed. Later, in the fifth step, a review of the statistics is provided and I4.0 applications are recognized. A conceptual framework is proposed in the sixth step. The findings are concluded and future studies recommendations are presented in the last step. The same approaches have been used in different works including Mehdiabadi et al. [25] for designing a road map for banking systems using I4.0, Toorajipour et al. [26] for developing the impact of artificial intelligence in supply chain management, and Xi and Hamari [27] on the virtual reality in shopping and purchasing. 


\section{Review Discussion and Findings}

\subsection{Demographics}

\subsubsection{Year-Wise Publications}

To illustrate the trend of the number of papers published in recent years, we studied papers from 2015-2020 (see Figure 2). The initial impression from the chart is that in both categories of keywords, an increase is illustrated in the number of papers in the last six years which display the importance of this topic.

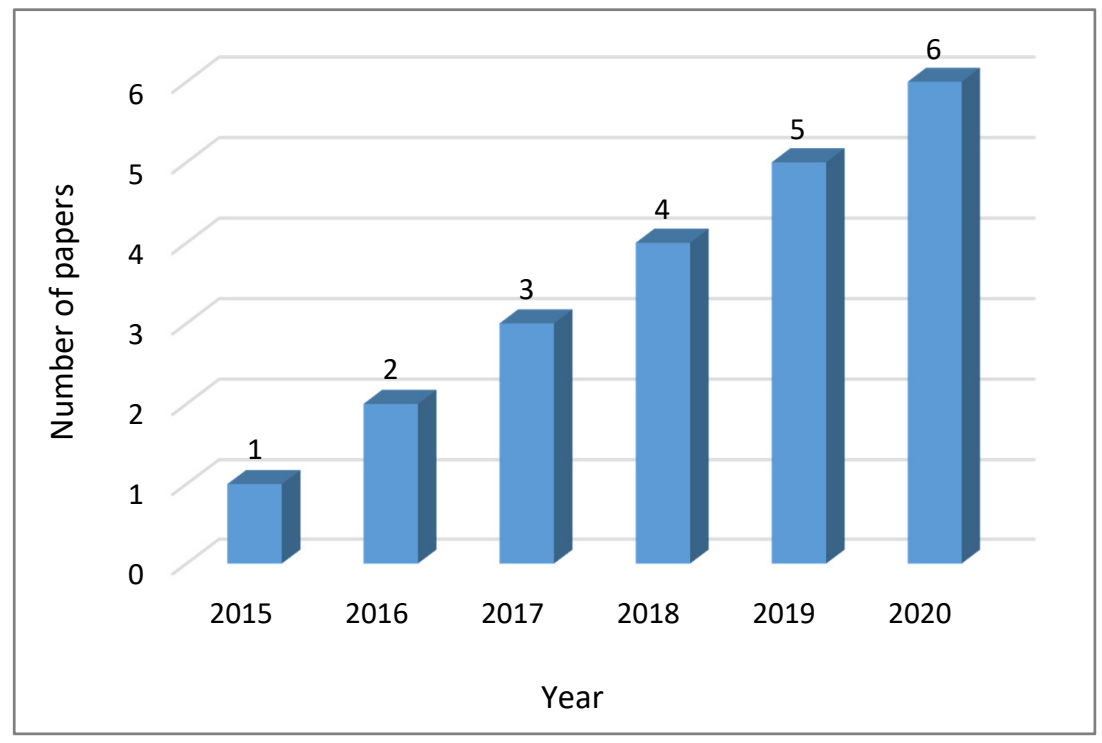

Figure 2. Year-wise publication details (Source: Author).

\subsubsection{Contributions by Publishers}

The contribution made by different publishers is analyzed. Elsevier has the maximum number of publications with 26 papers and followed by IEEE and Springer with 12 papers. A summary of this contribution is exposed in Figure 3.

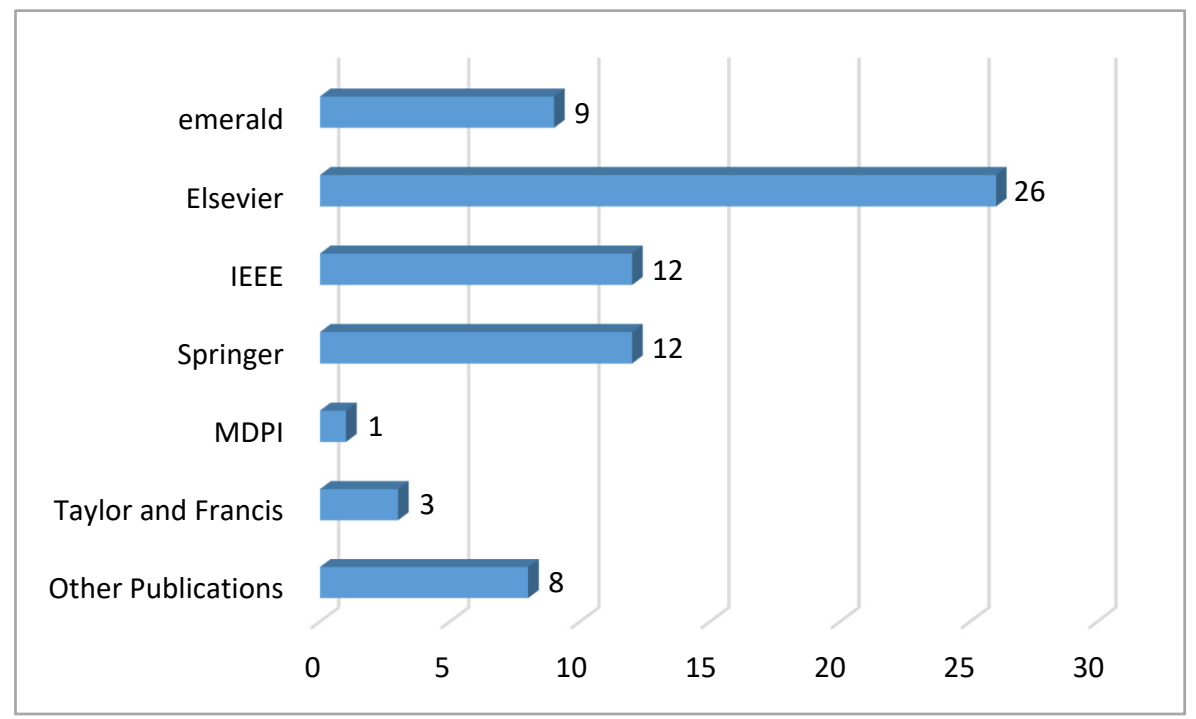

Figure 3. Contributions from publishers (Source: Author).

\subsubsection{Distribution of Papers Structures}

The papers studied in this SLR follow a specific structure to define their objectives and develop a methodology to provide a solution. As the main issue in this study is investigating the impact of I4.0 technologies on procurement, around one-third of identified 
papers consider a case study or mathematical model to deal with the related issues, which increase the rate of validity and can be applied in real-domain problems. Around $19 \%$ of papers considered a conceptual framework which is just a theory and does not contain any mathematical model or case. The least percentage (around 13\%) is for papers considering the questionnaire (see Figure 4).

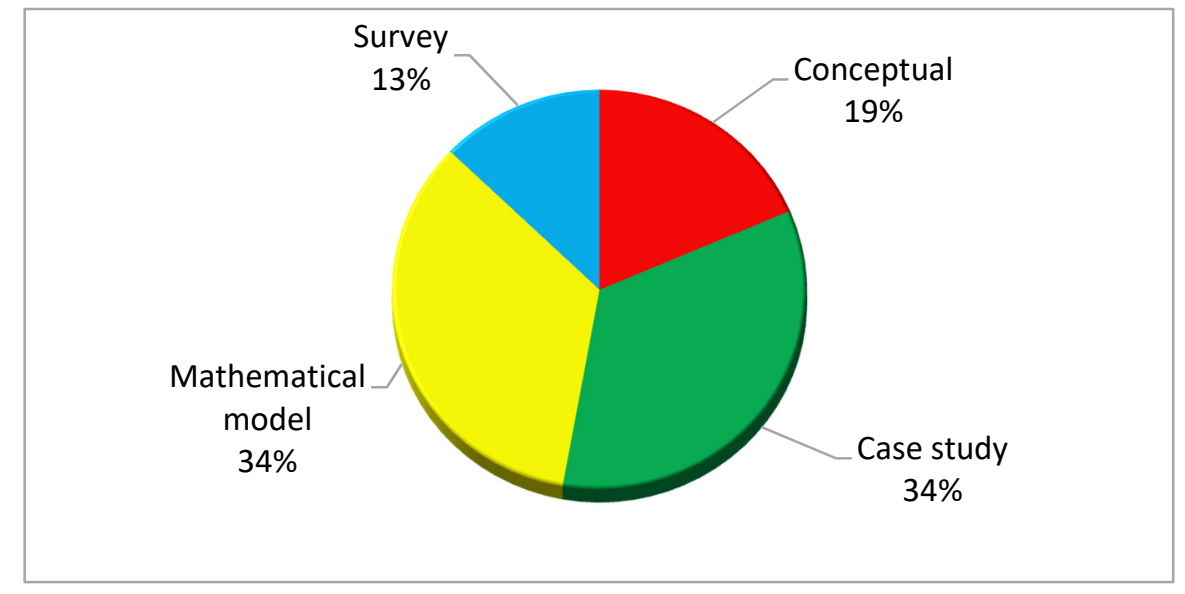

Figure 4. Frequency of the papers' structures (Source: Author).

\subsubsection{Contributions by Country}

The authors' affiliations with different countries are gathered and it is illustrated that China and India are the countries that have the highest contributions based on the number of papers. UK and Germany are next on this list (see Figure 5).

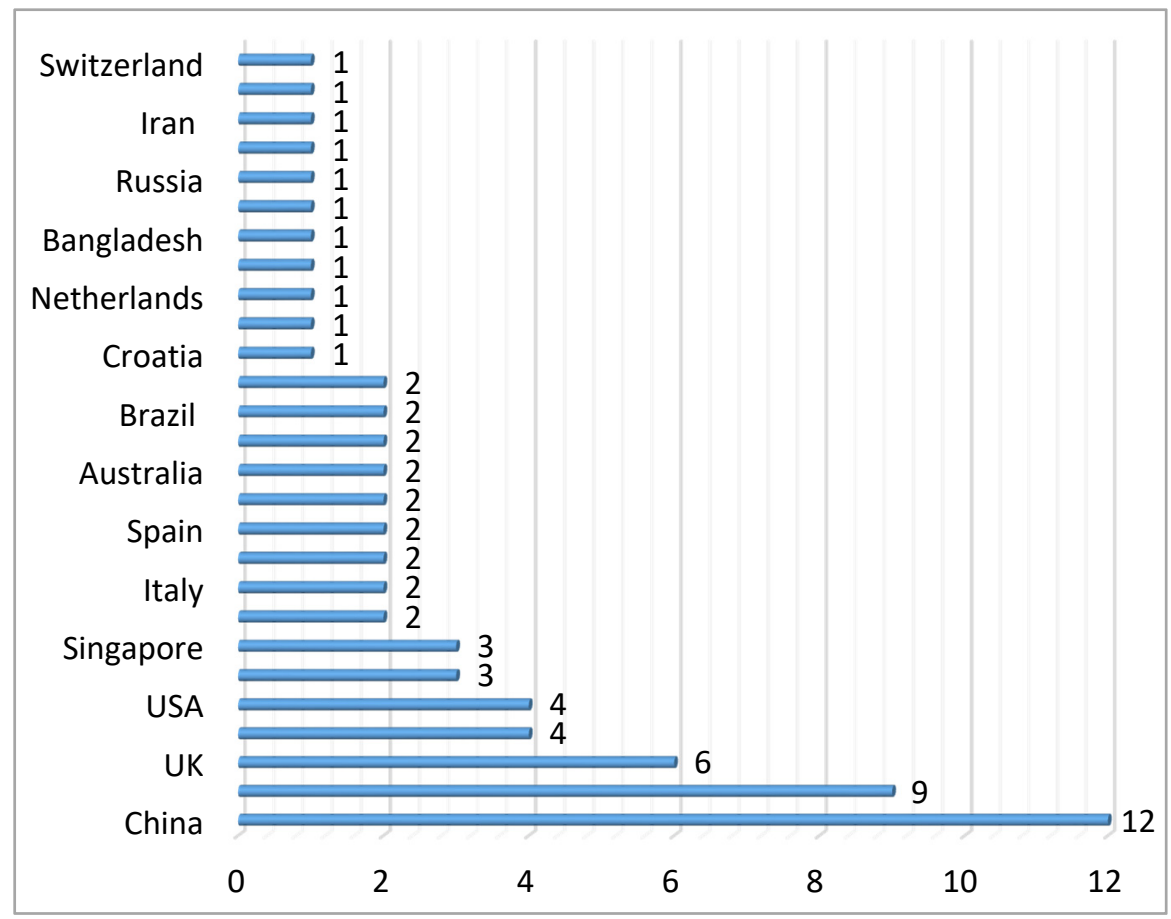

Figure 5. Country-wise publication details (Source: Author).

3.1.5. Distribution of the Most Attended Values Proposed in Procurement Using I4.0

Looking closely at the literature, the value-added benefit of procurement to the companies can be extracted which is ordered in the pie chart below. Purchasing performance management is the most important value and alongside supplier performance, management and supplier selection and evaluation enhancement are assigned the most key I4.0 
applications. The summary of the distribution of the most attended values in procurement is illustrated in Figure 6.

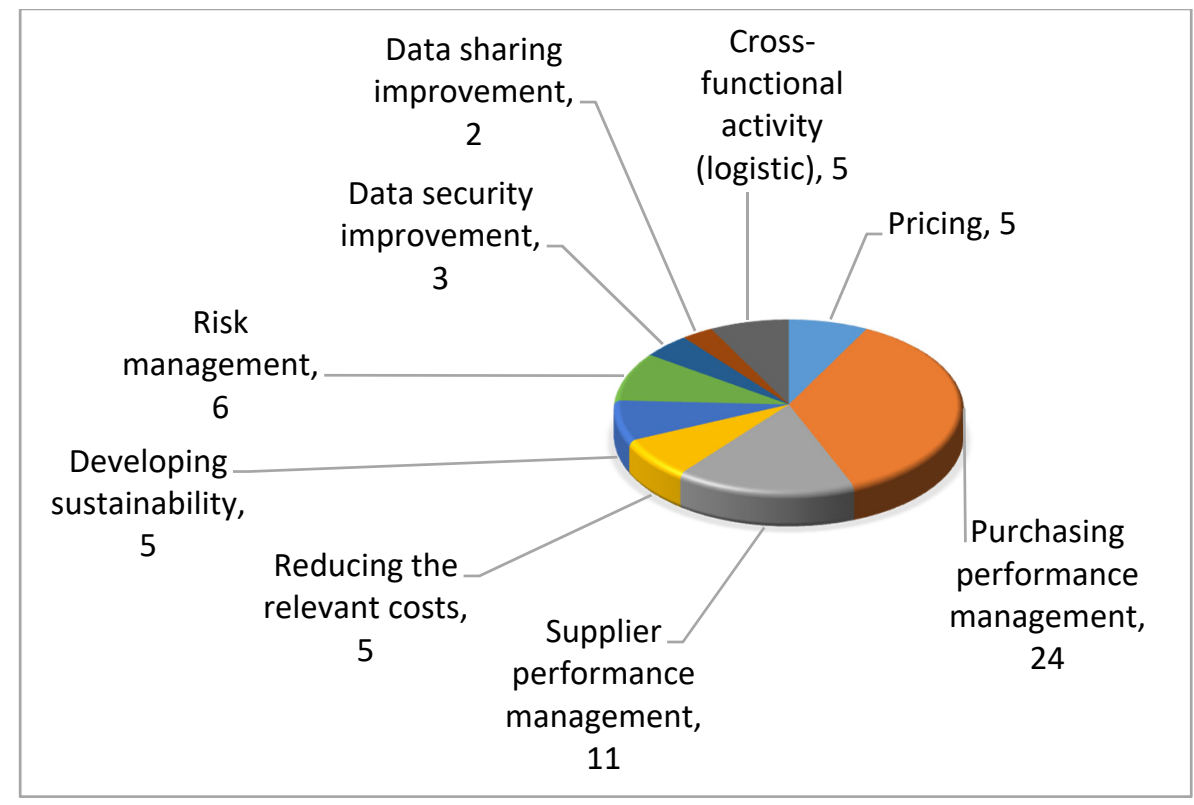

Figure 6. Distribution of the most attended maritime transportation risks (Source: Author).

\subsubsection{Distribution of the Most Applied I4.0 Applications}

According to the literature, the number of articles considering different procurement technologies is illustrated in the pie chart below. BDA and IoT are two important elements that can have a striking impact on proposing values in the procurement domain. The most important I4.0 applications utilized to add value to procurement processes are summarized in Figure 7.

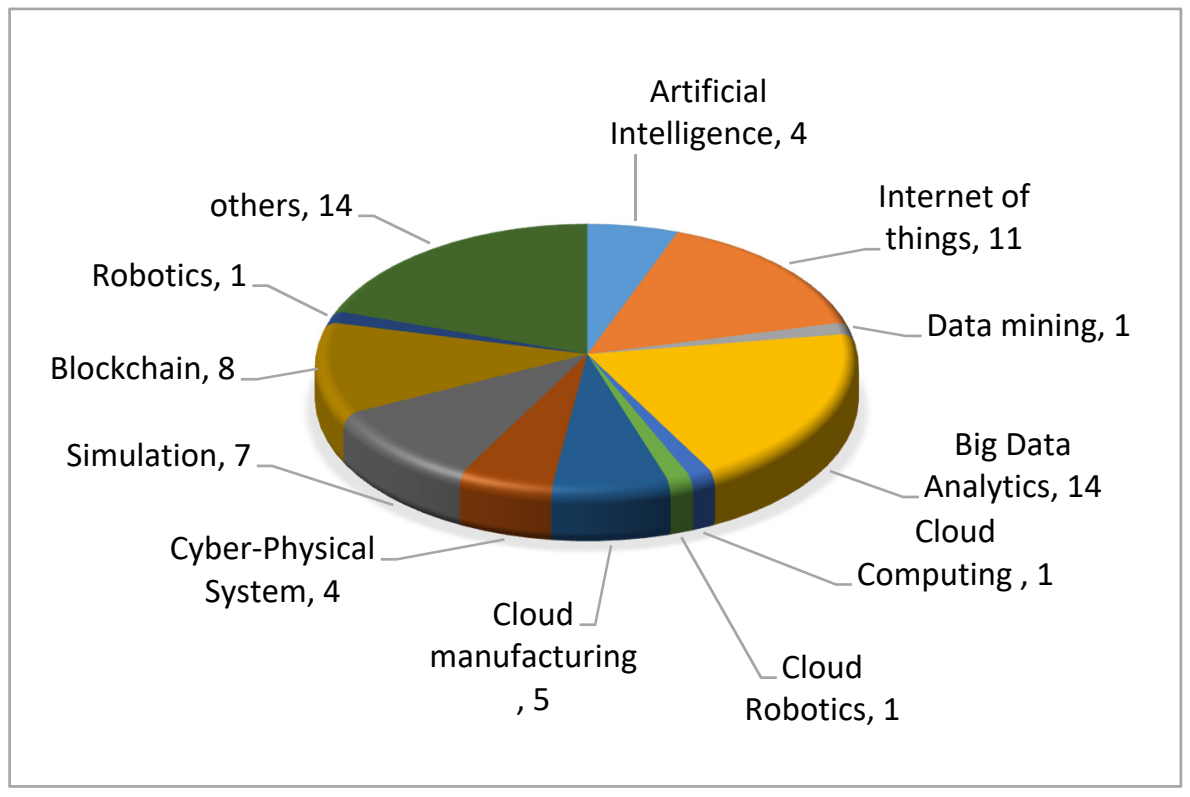

Figure 7. Distribution of the most applied I4.0 applications (Source: Author).

\subsection{Key I4.0 Applications Associated with Procurement}

The digitization of procurement can lead to supporting daily business tasks, facilitating complicated decision-making, and emphasizing strategic activities [28]. Selecting different I4.0 technologies requires an appropriate Technology Acceptance Model (TAM) in the 
procurement domain which defines different indicators to determine the adoption and application of each technology [29]. Procurement technologies emphasize some of the functions and processes such as e-sourcing, contract management, and e-procurement [30]. The most important I4.0 applications in the SC are summarized in Table 1. Then, in Section 4 , we discuss the values that I4.0 applications can add to the procurement processes.

Table 1. I4.0 applications in SC (Source: Author).

\begin{tabular}{|c|c|c|c|}
\hline I4.0 Technology & Definition & Application in SC & Source \\
\hline Internet of Things & $\begin{array}{l}\text { Interconnection of sensing and } \\
\text { actuating devices providing the ability } \\
\text { to share the information across } \\
\text { platforms through a unified framework, } \\
\text { developing a common operating } \\
\text { picture for enabling innovative } \\
\text { applications [31] }\end{array}$ & $\begin{array}{l}\text { Detecting raw materials and } \\
\text { mare products } \\
\text { Proposing after-sales service in a } \\
\text { contribution to products } \\
\text { - } \quad \text { Autonomous decision-making } \\
\text { Quality monitoring and } \\
\text { quality-controlled logistics } \\
\text { Collecting the data from in used products }\end{array}$ & [32-37] \\
\hline Cloud Computing & $\begin{array}{l}\text { A model for enabling ubiquitous, } \\
\text { convenient, on-demand, network } \\
\text { access to a shared pool of configurable } \\
\text { computing resources that can be } \\
\text { rapidly provisioned and released with } \\
\text { minimal management effort or service } \\
\text { provider interaction [38] }\end{array}$ & $\begin{array}{ll}\text { - } & \text { Manufacturing integration using } \\
\text { electrical equipment } \\
\text { - } & \text { Human factors management } \\
\text { - } & \text { Mitigating SC risk } \\
\text { - } & \text { logistics system } \\
\text { - } & \text { Dustomer order management } \\
& \text { Dassification }\end{array}$ & [39-45] \\
\hline $\begin{array}{l}\text { Cyber-Physical } \\
\text { Systems }\end{array}$ & $\begin{array}{l}\text { A system that uses sensors and } \\
\text { actuators to gather physical data and } \\
\text { affect physical processes using } \\
\text { multi-modal human-machine } \\
\text { interaction [46] }\end{array}$ & $\begin{array}{l}\text { - Increasing security and resilience } \\
\text { - Improving decision-making and } \\
\text { understanding processes } \\
\text { - Combination of standards using a large } \\
\text { amount of data } \\
\text { - Interchanging information }\end{array}$ & {$[3,44,47-49]$} \\
\hline Big Data Analysis & $\begin{array}{l}\text { High volume, high-velocity, and } \\
\text { high-variety sets of dynamic data } \\
\text { exceed the processing capabilities of } \\
\text { traditional data management } \\
\text { approaches [50] }\end{array}$ & $\begin{array}{l}\text { - } \quad \text { Quality problems and material } \\
\text { availability } \\
\text { - } \quad \text { Supply risk mitigation } \\
\text { - } \quad \text { Analyze supplier performance for } \\
\text { better sourcing } \\
\text { - } \quad \text { Improve decision-making }\end{array}$ & [51-55] \\
\hline Robotics & $\begin{array}{l}\text { A technology that allows companies to } \\
\text { decrease the human interventions and } \\
\text { facilitate the operations [56] }\end{array}$ & $\begin{array}{ll}\text { - } & \text { Efficient production and material tracking } \\
\text { - } & \text { Smart delivery } \\
\text { - } & \text { Less workforce to increase the efficiency }\end{array}$ & {$[57,58]$} \\
\hline Blockchain & $\begin{array}{l}\text { A distributed database of records or } \\
\text { shared public/private ledgers of all } \\
\text { digital events that have been executed } \\
\text { and shared among blockchain } \\
\text { participating agents [59] }\end{array}$ & $\begin{array}{l}\text { - } \\
\text { - } \quad \text { Allowresenting all the information related } \\
\text { information of the products } \\
\text { - } \\
\text { - } \\
\text { Dutomatically update transactions } \\
\text { emissions in the production system }\end{array}$ & [60-63] \\
\hline
\end{tabular}


Table 1. Cont.

\begin{tabular}{|c|c|c|c|}
\hline I4.0 Technology & Definition & Application in SC & Source \\
\hline $\begin{array}{c}\text { Smart } \\
\text { manufacturing }\end{array}$ & $\begin{array}{l}\text { Contribution of information, } \\
\text { communication, and production } \\
\text { technology in SC domain to maintain } \\
\text { the balance of demand and supply, and } \\
\text { to maximize customer satisfaction with } \\
\text { minimum cost [64] }\end{array}$ & $\begin{array}{l}\text { - } \quad \text { Share the information intelligently } \\
\text { Providing collaboration between the } \\
\text { actors of the SC } \\
\text { Enhancing the flexibility } \\
\text { of manufacturing } \\
\text { Improve productivity }\end{array}$ & {$[3,65-67]$} \\
\hline Artificial Intelligence & $\begin{array}{l}\text { A field of computer science and } \\
\text { engineering concerned with the } \\
\text { computational understanding of what } \\
\text { is commonly called intelligent behavior, } \\
\text { and with the creation of artifacts that } \\
\text { exhibit such behavior [68] }\end{array}$ & 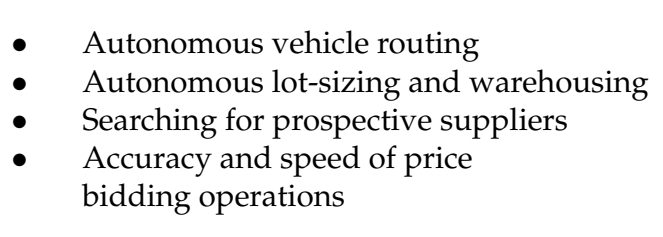 & [69-72] \\
\hline Simulation & $\begin{array}{l}\text { A method to draw a system with } \\
\text { uncertainties of its all elements to } \\
\text { improve its performance according to } \\
\text { its requirements }\end{array}$ & $\begin{array}{l}\text { - } \quad \text { SC planning and scheduling } \\
\text { - } \quad \text { Information sharing/coordination } \\
\text { mechanisms } \\
\text { - Uncoordinated ordering } \\
\text { behavior distortion } \\
\text { - Inventory management }\end{array}$ & [73] \\
\hline
\end{tabular}

As P4.0 is one of the most important concepts in the smart SC [28], we discuss it in the next section and all the values added by I4.0 applications in the procurement domain are investigated.

\section{Conceptual Framework Regarding the Values Proposed in Procurement}

In this section, according to the literature and the quantitative analysis, we identified nine major procurement values that can be proposed by using I4.0 applications. The results in Figure 8 present the visual framework of the main I4.0 applications in providing those value propositions. Since procurement can be determined as a mixture of purchasing with inventory control, transportation, receiving, inspection, storekeeping, and salvage and disposal operations, procurement professionals must comply with the strategic goals and the company's procurement objectives to propel the companies into success [74]. Table 2 summarizes the papers reviewed in this elaboration.

Table 2. Summary of the reviewed papers (Source: Author).

\begin{tabular}{|c|c|c|c|c|}
\hline Reference & I4.0 Aspect & Values Proposed in Procurement & Methodology & Structure \\
\hline Chou et al. [75] & Artificial intelligence & Pricing & Genetic algorithm & Cased-base \\
\hline Jie et al. [76] & Internet of Things & Supplier selection and evaluation & Structural equation modeling (SEM) & Conceptual \\
\hline AlKhalifah and Ansari [77] & Data Mining & Supplier selection and evaluation & Linear regression model & Cased-base \\
\hline Bag $[78]$ & Big Data analysis & $\begin{array}{l}\text { Purchasing performance } \\
\text { management }\end{array}$ & Fuzzy (VIKOR) method & Mathematical model \\
\hline Ellram and Tate [79] & Big Data analysis & $\begin{array}{l}\text { Purchasing performance } \\
\text { management }\end{array}$ & Literature review & Cased-base \\
\hline Fazekas et al. [80] & Big Data analysis & Risk management & Crawler algorithm & Cased-base \\
\hline Glas and Kleemann [3] & Internet of Things & $\begin{array}{l}\text { Purchasing performance } \\
\text { management }\end{array}$ & Literature review & Conceptual \\
\hline Gleeson and Walden [45] & Cloud computing & Data security improvement & Robust data classification & Cased-base \\
\hline Wang et al. [10] & Cloud Robotics & Supplier selection and evaluation & Stackelberg game model & Mathematical model \\
\hline Zhao-yang et al. [81] & Cloud manufacturing & Pricing & Genetic algorithm & Mathematical model \\
\hline Mladineo et al. [82] & Cyber-Physical Systems & $\begin{array}{l}\text { Supplier performance } \\
\text { management }\end{array}$ & HUMANT algorithm & Mathematical model \\
\hline Moretto et al. [83] & Big Data analysis & Reducing the relevant costs & Case-based issues & Survey \\
\hline Trappey et al. [84] & Internet of Things & $\begin{array}{l}\text { Supplier performance } \\
\text { management }\end{array}$ & Literature review & Survey \\
\hline You et al. [85] & Simulation & $\begin{array}{l}\text { Supplier performance } \\
\text { management }\end{array}$ & Transaction analysis & Mathematical model \\
\hline Abolbashari et al. [86] & Smart technology & $\begin{array}{l}\text { Purchasing performance } \\
\text { management }\end{array}$ & Bayesian Network Modeling (BNM) & Mathematical model \\
\hline Bienhaus and Haddud [28] & Procurement 4.0 & $\begin{array}{l}\text { Purchasing performance } \\
\text { management }\end{array}$ & $\begin{array}{c}\text { Challenge recognition using } \\
\text { interview }\end{array}$ & Conceptual \\
\hline Choi et al. [87] & Big Data Analysis & $\begin{array}{l}\text { Purchasing performance } \\
\text { enhancement }\end{array}$ & Fuzzy Cognitive Map (FCM) & Mathematical model \\
\hline Chopra [88] & Smart manufacturing & Reducing the relevant costs & Literature review & Survey \\
\hline Enayet et al. [89] & Big Data Analysis & $\begin{array}{l}\text { Purchasing performance } \\
\text { enhancement }\end{array}$ & Transaction analysis & Mathematical model \\
\hline Jeong et al. [90] & Internet of Things & $\begin{array}{c}\text { Purchasing performance } \\
\text { enhancement }\end{array}$ & Auction-based algorithm & Mathematical model \\
\hline
\end{tabular}


Table 2. Cont.

\begin{tabular}{|c|c|c|c|c|}
\hline Reference & I4.0 Aspect & Values Proposed in Procurement & Methodology & Structure \\
\hline Kaur and Singh [91] & & Developing sustainability & Heuristic algorithm & Mathematical model \\
\hline Li et al. [92] & $\begin{array}{c}\text { Cyber-Physical Internet of } \\
\text { Things }\end{array}$ & $\begin{array}{l}\text { Purchasing performance } \\
\text { enhancement }\end{array}$ & Dinkelbach's algorithm & Mathematical model \\
\hline Lin et al. [93] & Cloud manufacturing & Supplier selection and evaluation & $\begin{array}{l}\text { decomposition-based-multi- } \\
\text { objective evolutionary } \\
\text { algorithm }\end{array}$ & Cased-base \\
\hline Macrinici et al. [94] & Blockchain & $\begin{array}{l}\text { Purchasing performance } \\
\text { management }\end{array}$ & Systematic mapping approach & Cased-base \\
\hline Nicoletti [95] & Simulation & $\begin{array}{l}\text { Purchasing performance } \\
\text { management }\end{array}$ & Literature review & Conceptual \\
\hline $\begin{array}{l}\text { Osmonbekov and } \\
\text { Johnston [12] }\end{array}$ & Internet of Things & $\begin{array}{l}\text { Purchasing performance } \\
\text { management }\end{array}$ & buying behavior theory & Conceptual \\
\hline Pinochet et al. [96] & Internet of things & $\begin{array}{l}\text { Purchasing performance } \\
\text { management }\end{array}$ & Interview & Cased-base \\
\hline Rejeb et al. [30] & Smart technologies & $\begin{array}{l}\text { Purchasing performance } \\
\text { management }\end{array}$ & Literature review & Survey \\
\hline Singh et al. [97] & Cloud manufacturing & Developing sustainability & Fuzzy AHP, DEMATEL, and TOPSIS & Case-based \\
\hline Song et al. [98] & Big Data analysis & Supplier performance & Deep learning model & Mathematical model \\
\hline Sun et al. [99] & Big Data analysis & Pricing & Dynamic pricing iterative algorithm & Mathematical model \\
\hline $\begin{array}{l}\text { Tönnissen and } \\
\text { Teuteberg [100] }\end{array}$ & Blockchain & $\begin{array}{l}\text { Supplier performance } \\
\text { management }\end{array}$ & Interview & Case-based \\
\hline Uygun and Ilie [101] & Smart manufacturing & $\begin{array}{l}\text { Supplier performance } \\
\text { management }\end{array}$ & Procurement processes management & Conceptual \\
\hline Wang et al. [102] & Cloud manufacturing & $\begin{array}{l}\text { Supplier performance } \\
\text { management }\end{array}$ & $\begin{array}{c}\text { TOPSIS model for supplier } \\
\text { evaluation }\end{array}$ & Mathematical model \\
\hline Wang et al. [103] & Cloud manufacturing & $\begin{array}{l}\text { Supplier performance } \\
\text { management }\end{array}$ & Distributed Genetic algorithm & Mathematical model \\
\hline Yin et al. [104] & Smart manufacturing & $\begin{array}{l}\text { Purchasing performance } \\
\text { management }\end{array}$ & Fog computing & Mathematical model \\
\hline Zhou et al. [105] & Internet of Things & $\begin{array}{l}\text { Purchasing performance } \\
\text { management }\end{array}$ & $\begin{array}{l}\text { Channel State Information (CSI) } \\
\text { model }\end{array}$ & Mathematical model \\
\hline Afrin et al. [106] & Robotics & $\begin{array}{c}\text { Purchasing performance } \\
\text { management }\end{array}$ & $\begin{array}{c}\text { Non-dominated Sorting Genetic } \\
\text { algorithm }\end{array}$ & Case-based \\
\hline Agarwal et al. [5] & Internet of Things & Supplier selection and evaluation & Multi-objective optimization & Case-based \\
\hline Akaba [7] & Blockchain & Data security improvement & Interview & Case-based \\
\hline Berru et al. [107] & Internet of Things & Risk management & Literature review & Survey \\
\hline Çalı and Balaman [108] & Big Data analysis & Supplier selection and evaluation & Multi-Criteria Decision-making & Case-based \\
\hline Cavalcante et al. [109] & Artificial intelligence & Supplier selection and evaluation & SC mapping & Conceptual \\
\hline Chang et al. [110] & Blockchain & Data-sharing improvement & Literature review & Conceptual \\
\hline Gavrilova et al. [111] & Blockchain & Risk management & Classification framework & Conceptual \\
\hline Ghadimi et al. [11] & Cyber-Physical Systems & Supplier selection and evaluation & Fuzzy-set theory & Case-based \\
\hline Handfield et al. [9] & Big Data analysis & $\begin{array}{l}\text { Purchasing performance } \\
\text { enhancement }\end{array}$ & Interview & Case-based \\
\hline Jordon et al. [112] & Artificial intelligence & $\begin{array}{l}\text { Purchasing performance } \\
\text { enhancement }\end{array}$ & DMAIC in total quality management & Conceptual \\
\hline Lamba and Singh [113] & Big Data analysis & Developing sustainability & $\begin{array}{l}\text { Mixed-integer non-linear } \\
\text { programming }\end{array}$ & Mathematical model \\
\hline $\begin{array}{l}\text { Layaq et al. [114] } \\
\text { Li et al. [115] }\end{array}$ & $\begin{array}{l}\text { Smart technology } \\
\text { Blockchain }\end{array}$ & $\begin{array}{l}\text { Risk management } \\
\text { Risk management }\end{array}$ & $\begin{array}{l}\text { Interview } \\
\text { Game theory for smart contracts }\end{array}$ & $\begin{array}{l}\text { Conceptual } \\
\text { Mathematical model }\end{array}$ \\
\hline $\begin{array}{l}\text { Muñoz-Garcia and } \\
\text { Vila [116] }\end{array}$ & Public procurement 4.0 & Pricing & Data gathering and analyzing & Conceptual \\
\hline $\begin{array}{c}\text { Oh and Jeong [64] } \\
\text { Rane and Thakker [117] }\end{array}$ & $\begin{array}{l}\text { Smart manufacturing } \\
\text { Blockchain }\end{array}$ & $\begin{array}{l}\text { Reducing the relevant costs } \\
\text { Developing sustainability }\end{array}$ & $\begin{array}{l}\text { SC network design } \\
\text { Literature review }\end{array}$ & $\begin{array}{l}\text { Mathematical model } \\
\text { Survey }\end{array}$ \\
\hline Sachdeva et al. [118] & Smart technology & $\begin{array}{l}\text { Supplier performance } \\
\text { management }\end{array}$ & Fuzzy entropy weight-based TOPSIS & Mathematical model \\
\hline Srai and Lorentz [119] & Smart technology & $\begin{array}{l}\text { Purchasing performance } \\
\text { enhancement }\end{array}$ & Literature review & Survey \\
\hline Akaba et al. [120] & Blockchain & $\begin{array}{c}\text { Purchasing performance } \\
\text { enhancement }\end{array}$ & Interview & Case-based \\
\hline Bag et al. [121] & Simulation & Developing sustainability & $\begin{array}{c}\text { Partial Least Squares Structural } \\
\text { Equation }\end{array}$ & Case-based \\
\hline Chen et al. [122] & Simulation & Supplier selection and evaluation & Hybrid rough-fuzzy DEMATEL & Case-based \\
\hline Gholizadeh et al. [123] & & Reducing the relevant costs & Heuristic method (MCDM) & Mathematical model \\
\hline $\begin{array}{l}\text { Ghosh et al. [124] } \\
\text { Gottge et al. [8] }\end{array}$ & $\begin{array}{l}\text { cyber-physical systems } \\
\text { Big Data analysis }\end{array}$ & $\begin{array}{c}\text { pricing } \\
\text { Data-sharing improvement }\end{array}$ & $\begin{array}{l}\text { SC network design modeling } \\
\text { Qualitative content analysis }\end{array}$ & $\begin{array}{l}\text { Mathematical model } \\
\text { Case-based }\end{array}$ \\
\hline Gupta et al. [125] & Simulation & Data security improvement & Zero-Knowledge Proof & Case-based \\
\hline Legenvre et al. [126] & Internet of Things & $\begin{array}{l}\text { Supplier performance } \\
\text { management }\end{array}$ & Interview & Conceptual \\
\hline $\begin{array}{l}\text { Nandankar and } \\
\text { Sachan [127] }\end{array}$ & E-procurement & $\begin{array}{c}\text { Purchasing performance } \\
\text { enhancement }\end{array}$ & Literature review & Survey \\
\hline Nicoletti [128] & Procurement 4.0 & $\begin{array}{l}\text { Purchasing performance } \\
\text { enhancement }\end{array}$ & Literature review & Survey \\
\hline Pu et al. [129] & Smart manufacturing & $\begin{array}{l}\text { Supplier performance } \\
\text { management }\end{array}$ & Agent-based SC model & Mathematical model \\
\hline Schulze-Horn et al. [130] & Artificial intelligence & $\begin{array}{l}\text { Purchasing performance } \\
\text { enhancement }\end{array}$ & Interview & Case-based \\
\hline Zhang et al. [131] & Simulation & Reducing the relevant costs & $\begin{array}{l}\text { Multi-population differential } \\
\text { artificial bee colony algorithm }\end{array}$ & Case-based \\
\hline Kaur and Singh [132] & Simulation & Risk management & a Mixed Integer Program (MIP & Case-based \\
\hline
\end{tabular}

In this mapping process, based on the content analysis of the works analyzed in the SLR in the database and bounded keywords, we identified the most significant value that every procurement department may offer. Pricing, purchasing performance management, supplier performance management, reducing relevant costs, sustainability development, 
risk management, data security improvement, data-sharing improvement, cross-functional activity (logistics) are classified as primary values that the procurement department may offer, according to the literature. In each category mentioned, we identified related I4.0 applications, which can assist procurement managers in supporting the proposed values.
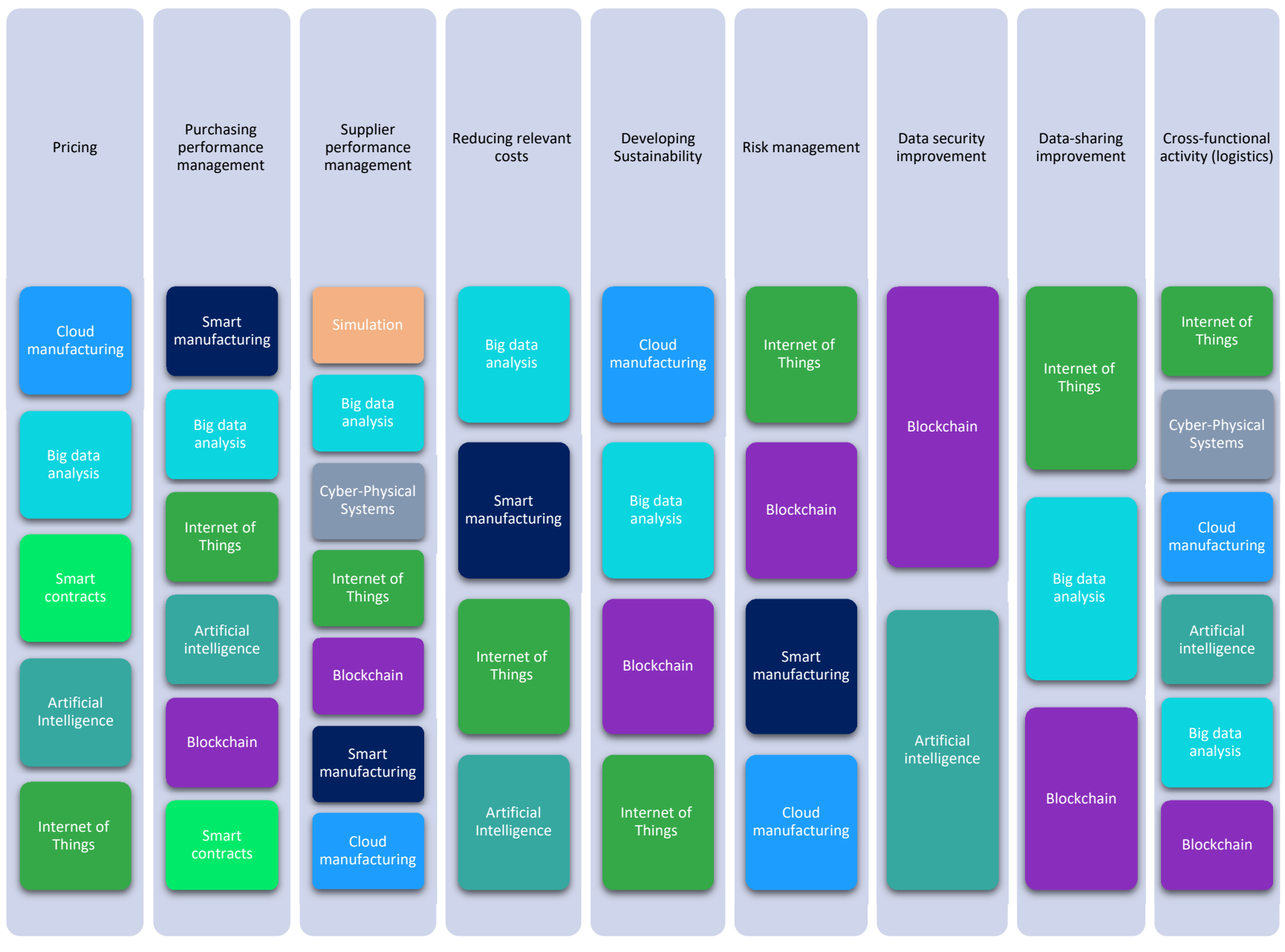

Figure 8. A conceptual framework on investigating the values proposed by implementing I4.0 technologies in procurement (Source: Author).

Nevertheless, there might be some other values that these applications may support and this study could not identify them because of our limitation in database and keywords. This issue will be addressed in the future studies and limitation sections of this study. To show the practicability of the proposed conceptual framework, the description of each procurement value includes examples of its practical applications and is presented in the following section and schematically in Figure 8.

\subsection{Pricing}

The role of predicting and assessing the price is undeniable to reach efficiency and effectiveness in the procurement process. As pricing is an important factor in selecting suppliers and allocating the orders, many price-dependent factors such as the distance between each supplier and user, the geographical distribution of resources, shipping costs, etc., should be counted in the responsibilities of the procurement managers [81]. Meanwhile, procurement managers should know that in some cases supplier offers the purchaser the opportunity to pay partial payment toward the total purchasing cost at the receiving time, and the due amount should be paid within an allowable period called the credit period [133]. Shipment cost as an overhead cost can be explained here to clarify the meaning of predicting prices. Since the transportation cost can be often paid by the 
purchasers [16], anticipating an optimal price where the benefit of the supplier is regarded simultaneously is necessary. As a result, embracing technologies that can observe the multi-objective transportation problem (MOTP) and found a Pareto optimal solution of MOTP are essential [16].

Several I4.0 technologies help procurement managers to anticipate prices. The first one is the cloud manufacturing service platform. The main role of cloud manufacturing in pricing is to consider the effects of different factors such as manufacturing conditions, variety of items, customer requirements, and delivery conditions to analyze them and find the optimal price in a supplier selection problem [81]. The second one is incorporating $\mathrm{BDA}$ and IoT altogether. In the resource allocation problem, auctions are held to determine the optimal price and BDA is an appropriate means to consider all aspects of an auction to allocate the resources [99]. Besides, costing, contracting, ordering, and auditing can be enhanced by the use of IoT technologies in which components can be connected and accessed directly to databases [126]. By scanning the artifacts, components can be costed owing to direct access to databases [126]. Another useful technology in this term is Smart contracts. Smart contracts in the public sector are a practical tool to analyze the price using valid databases and to win cross-border public contracts for the companies [116]. In addition to the previous examples, $\mathrm{AI}$ and data mining can facilitate the function of calculating prices from different suppliers, and the accuracy and speed of price bidding operations expedite through this I4.0 application [75]. A sufficient combination of AI and other techniques such as metaheuristic algorithms, multiple regression, and case-based reasoning (CBR) models can describe, test, and anticipate a correspondent price [75]. Since AI can learn different algorithms based on the previous data and can compare historical and validation data, this emerging technology is extremely powerful to solve complex problems [75]. The most effective learning algorithm for such technology is the backpropagation (BP) algorithm. For example, within the Taiwan government procurement system, contractors are estimating the project award prices optimally by using AI-based models to make bidding decisions [75].

\subsection{Supplier Performance Management}

The competitive environment of the market has led customers to use different methods to select and evaluate suppliers to enhance their performance. Different attributions are utilized to measure supplier performance [102]. The difference between delivered value and posted value that indicates the supply quality, uncertainty, and the flexibility that indicates the ability of the supplier to respond to fluctuations of demand or other necessities such as delivery time are two important attributions that can be simulated to measure and increase the supplier performance [85].

Delivering a specified product in the right location and quality at an affordable price makes a supplier reliable [109]. Therefore, the selection and evaluation of the suppliers before making a purchase can enhance the efficiency and effectiveness of the procurement processes, where the ultimate product cost can be justified. One of the technologies that meets this need is IoT in which all production elements and also products connect through the Internet by special tags, RFID systems, and websites. The Big Data obtained from the mentioned systems is stored in a cloud system that is accessible for future uses. In IoT, suppliers have to update static information with a unique identifier sold at different periods through the Internet. In this way, the IoT system can identify and recognize the changes in different factors such as materials, price, quality and can choose suitable suppliers for further collaboration. In this technique, products can be traced by the procurement department due to their tags [76]. If there is a need to decide and prioritize different issues in this smart mechanism, computers and machines solve them properly and inform every element in the whole network of what should be changed [10,44]. Moreover, BDA can predict the need of buyers for a single product according to the product characteristics which can enhance the procurement progress and regulate the number of supplies [98]. Decision support systems that use BDA can be applied to the supplier selection problems 
to assess and select the potential suppliers measuring the degree of satisfiability [118]. Particularly, this progress becomes important in the case of emergency products such as medicines [98]. Besides, selecting the appropriate suppliers involves considering various indicators such as capability index (market share and available logistics equipment), price index, and service indicator (task completion rate and exactitude rate) which can be defined to assess the performance of various suppliers and select the suppliers using proper decision-making methods [102]. Meanwhile, ordering progress can be improved efficiently by applying blockchain technology to the enterprise resource planning (ERP) system which can lead to the use of smart contracts in evaluating the suppliers and deciding for further communications [100].

Cloud manufacturing provides a decent platform to regulate the sequences of ordering resources from different suppliers by monitoring all orders placed which leads to an improvement in supplier selection [103]. In the production sector, using cyber-physical production network can lead to provide an autonomous production system termed cyberphysical production network (CPPN) which emphasizes selecting the suppliers using mathematical optimization [82]. "The mathematical model's function is smart in selecting the suppliers by considering their interest in supplying different items and operates different activities and then analyzes the price offered and the lead time autonomously to assign the orders and activities [82]." Smart manufacturing and using autonomous manufacturing can improve the performance of procurement by integrating the SC with engineering, centralizing SC business units, collaborative partnership in selecting the suppliers, and shortening the lead time, etc., [101]. Therefore, smart manufacturing can be a useful means in improving allocating the orders to specific suppliers by enhancing the flexibility, coordination, and integration of the SC network [129].

\subsection{Reducing the Relevant Costs}

Fluctuations in industry and expeditious development of information, communication, and production technologies (ICPT) have led to providing smart platforms to achieve a trade-off between the quality of goods or services provided and the costs associated with production and service procurement [64].

There are different types of costs associated with SC [5,122]. Two mainstream costs of SC are the cost of purchasing raw materials and the cost of maintaining the inventory at production sites. The purchasing cost consists of a large proportion of the total cost of production $[5,122]$. The companies are using the IoT by labeling their goods by identification tag and connecting the relevant information from these tags to the cloud through the Internet. Then, the uploaded data easily become accessible worldwide, and their associated companies (suppliers or vendors) can be connected for purchase. The system which is used in IoT has become a cost-effective solution and renders quicker decision-making capabilities in today's business environment. The principle goal of inventory management is to have a suitable product, in the right quantities, at an appropriate location, in time at affordable prices. In past decades, companies due to fluctuation of demand stored the raw material in-house, to stay in the market, and won a production competition, by meeting the needs on-site. Moreover, this strategy diminishes the unit cost, economic order quantity, retailer cost, and backorder quantity. Recently, as technologies like IoT have emerged, and the inventory cost has reduced significantly, they do not need to store in bulk warehouses. Because if there is a shortage, it is informed to other components by information uploaded to the cloud [5,122].

Using BDA can reduce procurement costs by providing better knowledge about the supply process in different phases such as supplier evaluation and marketing which leads to negotiation with suppliers to reduce the costs [83]. Using smart infrastructure in the manufacturing domain can lead to facilitating the procurement processes without human intervention and results in reducing the number of suppliers associated with the procurement processes and causes cost reduction [88]. Furthermore, a combination of $\mathrm{AI}$ and game theory, in which computer programs can learn algorithms according to 
past experiences, examples, analogies, rewards, or punishments, by their selves, build on machine learning (ML) and their efficiency improves over time. Both these fields are related to decision theory. With the contribution of AI methods, negotiations between parties could exist without expert interference. It can also decrease the preparation time for negotiations which ultimately reduces the vast majority of costs. AI could also diagnose the development of commodity or material price patterns, by accessing a database that includes detailed information about the cost structure of each supplier. Consequently, the optimal time and price for the purchasing process could be identified. AI with the algorithm it has learned can reduce cost. Recognizing the changes in the product that do not impair its functionality or the quality of the item, but can mitigate cost is regarded in AI. These changes might occur in the purchasing or engineering stage, and not only can AI reduce cost, but also it can lead to the avoidance of over-engineering. In this way, the breakdown costs that arose by suppliers could be recognized and assessed systematically and intelligently to lessen the imposition of hidden costs [130].

\subsection{Developing Sustainability}

The green supply chain has been defined as an integration of the environmental dimension in the supply chain, which includes product design, procurement, and material selection, manufacturing process, product delivery to final consumers, and end-of-life management of the product after its useful life [133,134], while a sustainable supply chain is a coordinated supply chain through the integration of economic, environmental, and social dimensions as three important pillar considerations [134]. These dimensions with key inter-organizational business systems are designed to benefit management of the material, information, and capital flows associated with the procurement, production, and distribution of products or services to meet stakeholder requirements and improve the profitability of the company over the term [134].

The I4.0 technologies could affect the design, manufacture, safety, cost efficiency, energy conservation, and environmental protection and in summary all three dimensions of sustainability [134]. For example, cloud systems can be utilized to develop sustainable procurement by considering different factors associated with sustainability such as carbon footprint (environmental) and waste disposal costs (economic), and social aspects [97]. Controlling the emissions and achieving a production rate with the lowest waste produced, where there is no possibility of fluctuation in the employment rate of workforce, optimize the cost and social aspects and can lead to optimizing the selection of suppliers and results in reducing carbon emissions [97]. Moreover, BDA can be applied to the SC to select the right suppliers not to waste money and workforce, and reduce the carbon emissions simultaneously by providing a dynamic framework for lot-sizing [113]. BDA mainly concentrates on providing a reliable database for forecasting the climate conditions which affect the transportation of items by suppliers and the carbon emissions in a time interval [113]. Furthermore, the integration of blockchain and IoT can identify the resources and schedule for using them to ensure the competitiveness of the SC and minimize energy usage and make waste disposal efficient [117].

Meanwhile, there is a new conception that has been recently investigated by researchers such as Bag et al. [121] and de Arroyabe et al. [135], which is "the circular economy." The circular economy can be defined as business models in which the surplus use of rare natural resources is minimized, and as a result, the amount of waste can be decreased [121]. This notion can lead the whole business model into considering sustainable development and operates on four levels: products, companies, networks, and policies [136]. In this field of study, the economic, social, and the environmental pillar are taken into account by increasing the rate of job satisfaction and job security, and IoT-based technologies such as GPS, RFID tags and sensors, Vehicular Ad-Hoc Networks (VANETS), shelf moving robots, smart mobile devices, and Automated Guided Vehicles (AGV) are used to inform the continuous logistics/information flow and transparency to executors by sensors and GPS systems [121]. 


\subsection{Risk Management}

Selecting and evaluating the suppliers in the e-procurement system is more challenging than traditional procurement because of the higher uncertainty and risks involved [84,85]. Risks can be divided into internal risks, supply chain risks, and external risks. Internal risks take place within the companies, while supply chain risks take place outside of the company but through the supply chain, and external risks take place outside of the supply chain in general [109]. Health, safety, and environmental regulations are significant concerns in smart factories. For example, factory fire is one of the types of risks within the company. A smart factory during a hazardous situation like this should integrate robot and cloud resources to process diversified tasks efficiently and timely. Optimal robots and cloud-based resource allocation for the functions of emergency management are essential in a smart factory. Edge cloud is one of the Cloud infrastructures which is brought out between the robot and cloud. This Cloud infrastructure provides data, computes, storage, and application service through the cloud. Hence, it can assist multi-robot systems in performing compute-intensive services as soon as possible in order not to harm the whole system in an emergency [106].

Digitalization and making the procurement processes smart can provide collaboration between different procurement processes and manage the risks related to procurement such as risks of damage, misplacing orders, negotiation, contract, and suppliers-related risks [114]. Mitigating the risks mentioned before are performed by improving the relationship between supplier and customer which results in decreasing the occurrence possibility of unexpected events [114]. Uncertainty of distribution networks caused by the flexibility of demand can be managed using smart contracts and blockchain technology by customizing information exchange, power transmission, pricing, and settlement and this leads to revising the design of distribution networks [115]. Furthermore, IoT can decrease the effects of uncertainty in the purchasing process. In this way by using IoT, human-to-machine communication increases to purchase a new product or modified rebuys $[8,126]$. Using IoT techniques such as operations research models, meta-heuristic networks, and supported vector machines can be utilized to provide metrics for evaluating procurement processes and decrease the possibility of corruption [107]. Simplifying transaction records, accelerating revenue management, and resolving conflicts, blockchain technology can provide the information security of public procurement, facilitate the progress of electronic tenders, and concluding contracts [111].

In the blockchain, transactions will be recorded permanently and unchangeable. This feature creates trust in the whole system. Blockchain also provides an unalterable audit sequence that allows participants to know who performed what action and when such action was performed. This characteristic of blockchain creates transparency and diminishes the associated risk of loss of information with third-party systems [120]. Big Data can help to control the risks associated with suppliers when a performance indicator is defined which leads to recognizing appropriate sourcing. Production scheduling can be proposed using machine learning methods for dynamic bottleneck analysis and risk detection. Scikit-Learn package is adopted in machine learning to define a Python module to integrate different problems [109].

\subsection{Data Security Improvement}

Since public procurement is defined as the buying of products and public or governmental service leading to economic growth, its data security is extremely sensitive. Data classification strategy for managing these databases is performed in almost every country. This strategy is to allocate the data to the various pre-defined groups which demonstrate controlling the security level of the database. Security standards adopt a classification of standard components instead of legal policies. It seems that CC technology can respond to this need properly. Classification of data and decide on which data should be shown to the public freely and unchangeably and which should be secured and hidden from common people. Some authorities can fully access this information, while the flow of all 
data in all SC existed [45]. The core function of government activities is public procurement that may lead to economic growth and development only when performed efficiently and transparently. Blockchain is a system that records transactions in an efficient, verifiable, and permanent setup and it is represented by censorship resistance, global usability, and immutability and has a vast network of validators called miners who maintain it through block rewards, named crypto tokens. Blockchains can provide security, ensure anonymity, and enhance the data integrity of transactions without the third party involvement. It contains a distributed system consisting of different stand-alone computers connected to one network for easy communication. This means that there is no central node for these systems, hence, one system failure does not affect other systems' performance. On the other hand, asymmetric cryptography is defined in this system. These features can pair public and private keys, allowing anonymous users to interchange information that is encrypted. In this technology, each information stored in a block and linked to the preceding block to be valid and thereby creates a chain of blocks $[7,125]$. Data security is significant for private companies as well. Even for private company suppliers, for example, it is very important to save and secure the scanned copies of purchase orders by interchanging them directly and by using electronic data interchange. Still, there is so much resistance to these new emerging technologies. Moreover, AI techniques that can learn different algorithms in SC could contribute to detecting destructive behavior using transaction patterns. A combination of $\mathrm{BC}$ and $\mathrm{AI}$ empowers the analysis and can lead to a more complex and compelling SC. Extracted data over the $\mathrm{BC}$ is available in the public sector; therefore, the role of $\mathrm{AI}$ in maintaining privacy has become significant. In this situation hacking a $\mathrm{BC}$ network is almost impossible because hackers need higher mining power. In a malicious situation when the attack is unavoidable, AI can build an isolated environment to attain significant security [125].

\subsection{Data-Sharing Management}

In the blockchain, the sharing of databases between different sections of procurement operations is facilitated. Furthermore, the cash flow of procurement can be regulated using the blockchain. In the blockchain, different movements between the parties could record, and contract correspondents can recognize and regulate transactions in a secure way for paperless mode. The area of finance in procurement can be simplified by blockchain, where the transactions are secure [95]. Likewise, the adoption of IoT technologies may facilitate communication and information sharing between parties. For instance, the vast majority of performance information collected from machine learning can be shared with different parties of procurement management. It helps engineers to provide feedback faster to the purchasing center $[12,110]$. By using BDA, information can be collected in different data types to be utilized as practical knowledge. Smart algorithms can collect data based on economic calculations. This process can propose flexibility and integrity when the procurement processes are visible. IoT (e.g., sensors/RFID, devices, smartphones) enables the communication between purchasing parties and exchanging of information through Internet communications protocols, Bluetooth, and $\mathrm{Wi}-\mathrm{Fi}$, [8].

\subsection{Purchasing Performance Management}

With the help of technological improvement, traditional purchasing supply management (PSM) activities, such as costing, contracting, ordering, and auditing can be reinforced. By collecting all activities and connections associated with the purchasing, the efficiency of tasks about purchasing is increased with a shift from traditional progress to smart progress $[30,119,127,128]$. Challenges in purchasing performance measurement can be exposed by interviewing employees who are directly associated with purchasing activities [28]. Therefore, measuring purchasing performance captures a specific aspect of the company's performance [86]. To measure the purchasing performance, a smart buyer defines different key performance indicators (KPIs) such as purchasing cycle time, emergency purchasing, sustainable purchasing, and purchasing integrity and makes effort 
to improve the purchasing performance by managing, improving, and integrating the KPIs [86]. In the case of purchasing items in service sectors such as healthcare systems, the quality, cost and lead time, social and environmental factors of an item become important and AI can be used to forecast techniques to learn the pattern of demand for an item by accumulating knowledge through repetitive learning activities [112]. Another example of improving purchasing performance is using the IoT devices such as actuators, sensors, and controllers to develop an efficient energy consumption system and increase the diversity and flexibility of allocating resources by tracking the orders [105].

Using blockchain, procurement departments can effectively exchange data with their suppliers which can be a valuable tool in managing issues such as quality and quotes of vendors along with ownership and contract challenges [95]. Companies can utilize this technology to rapidly determine delivery incompatibilities by dynamic data extraction within the ordering process. Moreover, it can reduce the complaints from rejected vendors by the gathered database from vendors that can be stored in a blockchain platform to remain immutable and irrevocable [95]. With the emergence of blockchain, smart contracts have become a more popular technology due to the customizability they add to the transactions. Smart contracts resemble real contracts except they are completely digital. Different blockchain platforms can be utilized to develop smart contracts, the most common of them is Ethereum [94,95]. In the blockchain, the trust is monitored by the open-source code backed by cryptography. Moreover, smart contracts contain the database of contractual agreements in the real domain [94,95].

In the public procurement sector, blockchain technology can be applied to increase the trust and transparency among stakeholders which leads to involving citizens in evoking procurement project needs and enables clearer project monitoring and auditing [120]. In service procurement in the public sector, BDA develops a data-driven decision-making system to purchase the items more efficiently by assigning different values for specific purchasing decisions that can be validated by different indices and experts in the service domain [87].

Ethereum is one of the most well-known decentralized platforms for smart contract applications. Users design the terms of their contracts by providing data structures and functions in contracts, and afterward, expand the contract on the blockchain. Contracts can negotiate with each other through their Ethereum addresses and application programming interfaces (APIs). Overall, smart contracts are computer codes that act on the blockchain platform to perform the terms of the agreement. Smart contracts can track the changes in the process status of different parties of a supply chain [110]. Furthermore, these contracts can be set up to activate the start of the subsequent process (e.g., payment transactions) [110].

Moreover, in IoT, machines are the ones who diagnose the manufacture's need (smart inventory) by different sensors and artifacts that can be scanned. After identification of shortage, machines place orders and render real-time consumption data. By accessing directly to the database, components can be a cost [126]. Auditing processes can be boosted by virtual reality, IoT devices (telematics or drones equipped with sensors), and access to unstructured datasets [126]. In traditional contracts procurement managers are very much involved in the transaction and they work in a human-to-machine (H2M) environment. At the same time, the transaction can be performed independently when adopting IoT. When sensors recognize a shortage of specific products, it transmits the identity of the product to the computer based on replenishment contracts and pricing decisions. Therefore, the order quantity will be calculated and the order is put to the supplier side by the computer [12].

\subsection{Cross-Functional Activity (Logistics)}

In the production and logistic aspect of SC, the lack of a transparent digital strategy is one of the main obstacles to deploy I4.0 technologies in the value creation process [137]. Looking closely at the final result of companies using IoT, CPS, Big Data technologies, and cloud-based services, they seem to be evaluated as having higher levels of logistic service, better cooperation among certain logistics functions, and higher financial and 
market performance $[25,137]$. Since a single-objective transportation problem (TP) is not adequate to solve complicated scenarios in real-life situations, a multi-objective optimization problem in logistics, where optimal decisions need to be taken in the presence of trade-offs between two or more conflicting objectives, should be taken into consideration $[16,19]$. The data collected by IoT sensors can be stored, processed, and shared by applying cloud computing [138]. Better levels of logistic service can create a saving value for procurement managers in terms of time and money, logistics and material handling costs, shorter lead times, and fewer shortages during shipment, which are the primary factors of profitability [137]. By using basic IoT technologies such as CPS, CPPS, and wireless sensor networks, the conscious and systematic analysis of the data received greater emphasis [137]. These frequently cheap technologies allow procurement managers to monitor the activities, operations, and processes of machines, materials, workers, and even products themselves in the virtual world and collect, analyze, and utilize real-time decision-making.

Furthermore, AI and Blockchain can be used for data exchange between the different actors in the logistics chain [138]. Thus these technologies can be attained for calculating transportation options matching the customers' needs or merging procurement systems [138]. Indeed, Blockchain technology allows for the establishment of Smart Contracts between the logistic department and procurement, which once agreed, can be run by autonomous programs without any human intervention and exposures [138].

\section{Discussion}

Procurement 4.0 (P4.0) can improve the supply chain performance by adding values and improving visibility and resilience. Increased visibility helps in material planning, thus significantly reducing lead times. The idea of P4.0 and the values added by this concept is a novel subject that is addressed rarely and suffers from great uncertainty due to the involvement of complex supply chain activities and multi-criteria decision-making. P4.0 provides an adaptive capability that provides various values for the procurement department. This can simplify the challenging decisions related to the implications of I4.0 technologies in the supply chain as it can show how these technologies can bring value to the companies' procurement process. P4.0 capability considers integrating external and internal for use in internal operations and the innovative capabilities can connect companies' inbuilt innovativeness to market-related gains [121].

\subsection{Theoretical Implications}

Extending the conceptual framework proposed by Bienhaus and Haddud [28], I4.0 will have an important impact on procurement and leverage the efficiency and effectiveness of "many-to-many" communications via shared platforms. The results of the study reveal that technologies like Artificial Intelligence, Big Data, and Internet-of-Things enable companies to automate and optimize their procurement process and support the organizational smart transformation. Therefore, companies should implement internal test environments to experiment with internal processes in real and extend the lessons learned toward the supply chains. The value chain model proposed by Porter [139] shows the organizational role of procurement is an activity supporting the primary activities (e.g., operations, marketing, service, etc.).). Furthermore, the importance of procurement to leverage the level of performance and collaboration between the supply chain parties are highlighted in the literature. Taken the results of the study into account, it can be stated that our framework integrated the main parts of the procurement with I4.0 technologies and discuss how these technologies proposed value in the related activities.

By developing a conceptual framework, this study seeks to find the values added to supply chains through the development of resources in activating P4.0. The objective of this study is to first identify the role of I4.0 technologies in procurement and second to investigate the effect of P4.0 on developing values in the procurement department. Our findings show that technological resources for using front and base technologies are essential to the activation of P4.0 systems. Such technological adaption can create 
different values in procurement. The results also reveal that I4.0 technologies improve the performance of procurement operations in supply chains. From the theoretical perspective, this paper tends to classify different values that can be proposed in a supply chain in the procurement sector. Besides, the contribution of authors from numerous countries to this subject in recent years is illustrated. Therefore, this investigation results in classifying P4.0 technologies and proposed values and helps researchers to realize the latest trends of P4.0 in the last two decades. Research gaps of this subject are derived and many directions for future investigations are outlined.

The literature review results emphasize the significance for companies to adapt to the fourth industrial revolution and, therefore, the digitization as a serious challenge with a high impact factor toward the future success or failure in supply chain management. Companies should not consider "if" they set up a digital strategy and make their supply chain environment ready for the digital transformation and take the required actions to bring the digital transformation to life. The impact of smart development on procurement has a positive character and companies should take the future role of procurement and supply chain network nodes into account when aligning their procedures and processes toward the smart supply chain. Besides, the procurement function should get ready to build the required capacities and capabilities to support the supply chain proposed values from the operations perspective. Finally, the discipline of supply chain management will be highly influenced by the new role of the procurement function as an important operation in the supply chain network.

\subsection{Managerial Implications}

Based on what was discussed, practitioners are confronting a diverse flood of information about new technologies applicable in supply chains. In this regard, procurement operations are a vital part of supply chain management and propel practitioners to develop P4.0 to propose values in supply chains. This paper extended a conceptual framework in Figure 8 to help practitioners determine which technology is applied for developing each value in procurement management. This framework also reveals the most frequent I4.0 applications in the supply chain and the most significant values that can be proposed by these applications. The road map of practitioners in this field of study mainly answers the following questions: Which P4.0 technologies are applicable in a supply chain? To what extent does the company have the proper facilities to adopt P4.0? Which procurement values can be developed in the supply chain and what is the role of P4.0 on this development? Which P4.0 technology results in higher impacts in the supply chain based on the challenges a supply chain is confronting? Four key noteworthy points can be addressed for practitioners from this study. First, managers need to focus on building technological resources in their companies. Second, P4.0 should be applied to enhance operations productivity. Third, the proposed values in this study should be aligned with the supply chain performance measures and strategies. The significant role of managers is to integrate Big Data analysis, Artificial Intelligence, and the Internet of Things to form the supply chain performance architecture. Finally, practitioners must emphasize the P4.0 policy for every operation in the supply chain to be able to pursue and adhere to the added values. From a managerial point of view, this paper can be utilized as a reference for $\mathrm{P} 4.0$ and its proposed values and presents a linkage between these two concepts. Important support for decision-making can be obtained in companies. Hereof, the conceptualized framework indicates that managing purchasing operations and the processes associated with supplier selection and evaluation are the most attended values in procurement management. Besides, Big Data analysis, the Internet of Things, and blockchain technology are the most frequent P4.0 applications to propose these values. This outcome leads companies to develop a strategic management framework to search for the most important values required to be developed in their supply chains and which technologies can be implemented according to the infrastructure of the supply chain. 


\subsection{Limitations}

The study demonstrates a general overview in analyzing the impact of I4.0 on procurement and the proposed values within the area of supply chain management. In addition, the results extend the existing publications using a combination of categorized keywords with a good diversification in the subject, relevance, and contribution. However, based on the scope of the study the data analysis is limited to the values that can be proposed in procurement operations and their future change within the area of supply chain management. Related disciplines and supply chain functions (e.g., marketing, sales, manufacturing, etc.) are not further considered in the systematic literature review. Using three databases to collect papers in this subject such as WoS, Scopus, and Scholar results in missing some relevant papers not indexed in these three databases. Thus, adopting a higher variety of databases can minimize the bias regarding the collected papers [140]. Keyword selection is another limitation of this study that leads investigators to limit their searching progress to the keywords found in the title and abstract of the papers. Many other classifications can be elaborated which might be missed in this study. For instance, the concentration of this study is on the proposed values, while one might consider operations associated with procurement management or develops a paper from a mathematical perspective. Due to the lack of papers discussing the role of cyber-physical systems on procurement management, this paper has proposed a general indication of this effect. In addition, this paper concentrates on reviewing scientific papers, and governmental obligations, patents, and industry documents are missed in this study.

\subsection{Implications for Future Studies}

Numerous implications can be addressed for investigators to this contribution. Based on the developed framework, the foundation of emerging technologies in P4.0 can be laid when a combination of two or more technologies are utilized. The impact of the developed technologies on other operations of supply chains such as transportation and inventory management can be studied. The degree of P4.0 implementation and its effect on business process optimization (considering all functions) has not been thoroughly investigated. Considering the identified added values in P4.0 planning, it is suggested that further work is required to understand how to measure and evaluate production planning in the context of I4.0. The low level of composite reliability on this measure may have influenced the lack of support for the hypothesis that P4.0 planning influences the intention to optimize procurement processes and this remains a consideration for future studies. Based on the main research gaps of this study, future studies can concentrate on the following concepts.

- How I4.0 and digital technologies affect the design of the supply network and what irrelevant processes can be omitted using smart technologies;

- How smart technologies can influence the labor force and what are the social and economic circumstances;

- How uncertainty and instability of the market can be tackled by the application of I4.0;

- The effect of I4.0 on different operations management issues such as vehicle routing problem, fleet assignment problem, and inventory management can be analyzed;

- Impact of different smart systems on procurement and SC that have not been studied in this paper;

- Determining how uncertainty and instability of the market can be tackled by the application of I4.0 [141].

Finally, a contribution of these issues to I4.0 technology will be assessed and the possibility of adding values can be discussed.

\section{Conclusions}

Applicable technologies such as CPSs, BDA, and IoT under the term P4.0 have represented substantial values in the supply chains. These added values consist of performance improvement in the operations associated with procurement management in supply chains such as pricing, supplier selection and evaluation, cost-efficacy, data gathering and analy- 
sis, and purchasing management. Adoption of P4.0 results in autonomy, flexibility, and transparency of operations associated with procurement management to optimize pricing, supplier management, and purchasing management decisions or elaborate sustainability and data-sharing security $[142,143]$. The outcomes of this paper are original and novel in comparison with the relevant papers that studied P4.0 in the literature $[28,95,121,144,145]$. Whereas, previous papers had a focus on comprehensive models [95], reviewing the impact of P4.0 on business functions of a supply chain [28,146-150], manufacturing modeling to optimize organizational procurement processes [121,151], developing resiliency in supply chains against disruptions [144], and resource planning to develop productivity in remanufacturing operations [145], this paper is the first contribution to the subject that employs a systematic literature review to emphasize the values obtained from the adoption of P4.0 into supply chains. Despite the sprouting literature in this field, it is obvious that there is a lack of comprehensive and systematic frameworks, strategies, and approaches for the implementation of I4.0 in the procurement processes of SCs. Hence, key drivers and obstacles of the application of I4.0 in SCs are found through following an SLR to the problem. I4.0 and making the SCs smart have made a significant impact on every aspect of our lives. Motivated by this speculation and taking the application of I4.0 in procurement into account, this study proposed an SLR to (i) discuss an approach to determine different I4.0 applications and procurement processes, and (ii) identify the values proposed by I4.0 in procurement. Considering these purposes, selecting the appropriate application of I4.0 technologies in sectors associated with procurement will be facilitated.

Author Contributions: Conceptualization, N.J. and A.S.; methodology, H.R.V. and E.B.T.; validation, H.R.V. and E.B.T.; formal analysis, N.J. and A.S.; investigation, E.B.T.; resources, N.J., A.S. and H.R.V.; writing-original draft preparation, N.J. and A.S.; writing—review and editing, H.R.V. and E.B.T.; visualization, E.B.T.; supervision, H.R.V. All authors have read and agreed to the published version of the manuscript.

Funding: This research received no external funding.

Institutional Review Board Statement: Not applicable.

Informed Consent Statement: Not applicable.

Conflicts of Interest: The authors declare no conflict of interest.

\section{References}

1. Tan, K.C. A framework of supply chain management literature. Eur. J. Purch. Supply Manag. 2001, 7, 39-48. [CrossRef]

2. Hahn, G.J. Industry 4.0: A supply chain innovation perspective. Int. J. Prod. Res. 2020, 58, 1425-1441. [CrossRef]

3. Glas, A.H.; Kleemann, F.C. The impact of industry 4.0 on procurement and supply management: A conceptual and qualitative analysis. Int. J. Bus. Manag. Invent. 2016, 5, 55-66.

4. Tupa, J.; Simota, J.; Steiner, F. Aspects of risk management implementation for Industry 4.0. Procedia Manuf. 2017, 11, 1223-1230. [CrossRef]

5. Agarwal, S.; Sharma, V.; Pughat, A. Supplier selection problem in IoT solutions. Int. J. Pervasive Comput. Commun. 2019, 15, 1. [CrossRef]

6. Huber, B.; Sweeney, E.; Smyth, A. Purchasing consortia and electronic markets-A procurement direction in integrated supply chain management. Electron. Mark. 2004, 14, 284-294. [CrossRef]

7. Akaba, T.I. A Framework for the Adoption of a Blockchain-Based e-Procurement System: A Case Study of Nigeria. Master's Thesis, Tallinn University of Technology, Tallinn, Estonia, 2019.

8. Gottge, S.; Menzel, T.; Forslund, H. Industry 4.0 technologies in the purchasing process. Ind. Manag. Data Syst. 2020, $120,4$. [CrossRef]

9. Handfield, R.; Jeong, S.; Choi, T. Emerging procurement technology: Data analytics and cognitive analytics. Int. J. Phys. Distrib. Logist. Manag. 2019, 49, 972-1002. [CrossRef]

10. Wang, L.; Liu, M.; Meng, M.Q.-H. A pricing mechanism for task oriented resource allocation in cloud robotics. In Robots Sensor Clouds; Springer: Berlin/Heidelberg, Germany, 2016; pp. 3-31.

11. Ghadimi, P.; Wang, C.; Lim, M.K.; Heavey, C. Intelligent sustainable supplier selection using multi-agent technology: Theory and application for Industry 4.0 supply chains. Comput. Ind. Eng. 2019, 127, 588-600. [CrossRef]

12. Osmonbekov, T.; Johnston, W.J. Adoption of the Internet of Things technologies in business procurement: Impact on organizational buying behavior. J. Bus. Ind. Mark. 2018, 33, 781-791. [CrossRef] 
13. Min, H. Artificial intelligence in supply chain management: Theory and applications. Int. J. Logist. Res. Appl. 2010, 13, 13-39. [CrossRef]

14. Saberi, S.; Kouhizadeh, M.; Sarkis, J.; Shen, L. Blockchain technology and its relationships to sustainable supply chain management. Int. J. Prod. Res. 2019, 57, 2117-2135. [CrossRef]

15. Wanner, J.; Heinrich, K.; Janiesch, C.; Zschech, P. How Much AI Do You Require? Decision Factors for Adopting AI Technology. In Proceedings of the Forty-First International Conference on Information Systems, Online, 13-16 December 2020.

16. Maity, G.; Roy, S.K.; Verdegay, J.L. Time variant multi-objective interval-valued transportation problem in sustainable development. Sustainability 2019, 11, 6161. [CrossRef]

17. Das, S.K.; Roy, S.K.; Weber, G.-W. Application of Type-2 Fuzzy Logic to a Multiobjective Green Solid Transportation-Location Problem With Dwell Time Under Carbon Tax, Cap, and Offset Policy: Fuzzy Versus Nonfuzzy Techniques. IEEE Trans. Fuzzy Syst. 2020, 28, 2711-2725. [CrossRef]

18. Das, S.K.; Pervin, M.; Roy, S.K.; Weber, G.W. Multi-objective solid transportation-location problem with variable carbon emission in inventory management: A hybrid approach. Ann. Oper. Res. 2021, 1-27. [CrossRef]

19. Midya, S.; Roy, S.K.; Vincent, F.Y. Intuitionistic fuzzy multi-stage multi-objective fixed-charge solid transportation problem in a green supply chain. Int. J. Mach. Learn. Cybern. 2021, 12, 699-717. [CrossRef]

20. Das, S.K.; Roy, S.K. Effect of variable carbon emission in a multi-objective transportation-p-facility location problem under neutrosophic environment. Comput. Ind. Eng. 2019, 132, 311-324. [CrossRef]

21. Sepehri, A.; Mishra, U.; Sarkar, B. A sustainable production-inventory model with imperfect quality under preservation technology and quality improvement investment. J. Clean. Prod. 2021, 310, 127332. [CrossRef]

22. Tranfield, D.; Denyer, D.; Smart, P. Towards a methodology for developing evidence-informed management knowledge by means of systematic review. Br. J. Manag. 2003, 14, 207-222. [CrossRef]

23. Paul, J.; Lim, W.M.; O'Cass, A.; Hao, A.W.; Bresciani, S. Scientific procedures and rationales for systematic literature reviews (SPAR-4-SLR). Int. J. Consum. Stud. 2021. [CrossRef]

24. Paul, J.; Criado, A.R. The art of writing literature review: What do we know and what do we need to know? Int. Bus. Rev. 2020, 29, 101717. [CrossRef]

25. Mehdiabadi, A.; Tabatabeinasab, M.; Spulbar, C.; Karbassi Yazdi, A.; Birau, R. Are we ready for the challenge of banks 4.0? Designing a roadmap for banking systems in industry 4.0. Int. J. Financ. Stud. 2020, 8, 32. [CrossRef]

26. Toorajipour, R.; Sohrabpour, V.; Nazarpour, A.; Oghazi, P.; Fischl, M. Artificial intelligence in supply chain management: A systematic literature review. J. Bus. Res. 2021, 122, 502-517. [CrossRef]

27. Xi, N.; Hamari, J. Shopping in virtual reality: A literature review and future agenda. J. Bus. Res. 2021, 134, 37-58. [CrossRef]

28. Bienhaus, F.; Haddud, A. Procurement 4.0: Factors influencing the digitisation of procurement and supply chains. Bus. Process Manag. J. 2018, 24, 965-984. [CrossRef]

29. Brandon-Jones, A.; Kauppi, K. Examining the antecedents of the technology acceptance model within e-procurement. Int. J. Oper. Prod. Manag. 2018, 38, 22-42. [CrossRef]

30. Rejeb, A.; Súle, E.; Keogh, J.G. Exploring new technologies in procurement. Transp. Logist. Int. J. 2018, 18, 1069-2406.

31. Gubbi, J.; Buyya, R.; Marusic, S.; Palaniswami, M. Internet of Things (IoT): A vision, architectural elements, and future directions. Future Gener. Comput. Syst. 2013, 29, 1645-1660. [CrossRef]

32. Bowman, P.; Ng, J.; Harrison, M.; Lopez, T.S.; Illic, A. Sensor based condition monitoring. In Building Radio Frequency IDentification for the Global Environ. (Bridge) Euro RFID Project; BRDGE: European Union, 2009.

33. Wang, T.; Zhang, Y.; Zang, D. Real-time visibility traceability framework for discrete manufacturing shopfloor. In Proceedings of the 22nd International Conference on Industrial Engineering and Engineering Management 2015, Singapore, 6-9 December 2015; pp. 763-772.

34. Rymaszewska, A.; Helo, P.; Gunasekaran, A. IoT powered servitization of manufacturing-an exploratory case study. Int. J. Prod. Econ. 2017, 192, 92-105. [CrossRef]

35. Jedermann, R.; Lang, W. The benefits of embedded intelligence-tasks and applications for ubiquitous computing in logistics. In The Internet Things; Springer: Berlin/Heidelberg, Germany, 2008; pp. 105-122.

36. Harris, I.; Wang, Y.; Wang, H. ICT in multimodal transport and technological trends: Unleashing potential for the future. Int. J. Prod. Econ. 2015, 159, 88-103. [CrossRef]

37. Kumar, V.; Amorim, M.; Bhattacharya, A.; Garza-Reyes, J.A.; Parry, G.C.; Brax, S.A.; Maull, R.S.; Ng, I.C. Operationalising IoT for reverse supply: The development of use-visibility measures. Supply Chain Manag. Int. J. 2016, 21, 2.

38. Mell, P.; Grance, T. The NIST Definition of Cloud Computing; NIST: Gaithersburg, MD, USA, 2011.

39. Tao, F.; Cheng, Y.; Zhang, L.; Nee, A.Y. Advanced manufacturing systems: Socialization characteristics and trends. J. Intell. Manuf. 2017, 28, 1079-1094. [CrossRef]

40. Golightly, D.; Sharples, S.; Patel, H.; Ratchev, S. Manufacturing in the cloud: A human factors perspective. Int. J. Ind. Ergon. 2016, 55, 12-21. [CrossRef]

41. Akbaripour, H.; Houshmand, M.; Fatahi Valilai, O. Cloud-based global supply chain: A conceptual model and multilayer architecture. J. Manuf. Science Eng. 2015, 137, 040913. [CrossRef]

42. Kong, X.T.; Fang, J.; Luo, H.; Huang, G.Q. Cloud-enabled real-time platform for adaptive planning and control in auction logistics center. Comput. Ind. Eng. 2015, 84, 79-90. [CrossRef] 
43. Lee, H. Framework and development of fault detection classification using IoT device and cloud environment. J. Manuf. Syst. 2017, 43, 257-270. [CrossRef]

44. Kamble, S.S.; Gunasekaran, A.; Gawankar, S.A. Sustainable Industry 4.0 framework: A systematic literature review identifying the current trends and future perspectives. Process Saf. Environ. Prot. 2018, 117, 408-425. [CrossRef]

45. Gleeson, N.; Walden, I. Placing the state in the cloud: Issues of data governance and public procurement. Comput. Law Secur. Rev. 2016, 32, 683-695. [CrossRef]

46. Acatech National Academy of Science and Engineering. Living in a Networked World. Integrated Research Agenda Cyber-Physical Systems (agendaCPS). 2015. Available online: http://www.cyphers.eu/sites/default/files/acatech_STUDIE_ agendaCPS_eng_ANSICHT.pdf (accessed on 15 September 2020).

47. DiMase, D.; Collier, Z.A.; Heffner, K.; Linkov, I. Systems engineering framework for cyber physical security and resilience. Environ. Syst. Decis. 2015, 35, 291-300. [CrossRef]

48. Frazzon, E.M.; Silva, L.S.; Hurtado, P.A. Synchronizing and improving supply chains through the application of cyber-physical systems. IFAC-PapersOnLine 2015, 48, 2059-2064. [CrossRef]

49. Hans, C.; Hribernik, K.A.; Thoben, K.-D. An approach for the integration of data within complex logistics systems. In Dynamics in Logistics; Springer: Berlin/Heidelberg, Germany, 2008; pp. 381-390.

50. Chen, L.-W.; Tseng, Y.-C.; Syue, K.-Z. Surveillance on-the-road: Vehicular tracking and reporting by V2V communications. Comput. Netw. 2014, 67, 154-163. [CrossRef]

51. Souza, G.C. Supply chain analytics. Bus. Horiz. 2014, 57, 595-605. [CrossRef]

52. Kabak, M.; Burmaoğlu, S. A holistic evaluation of the e-procurement website by using a hybrid MCDM methodology. Electron. Gov. Int. J. 2013, 10, 125-150. [CrossRef]

53. Khan, K. The transformative power of advanced analytics. Supply Chain Manag. Rev. 2013, 17, 48-49.

54. Oruezabala, G.; Rico, J.-C. The impact of sustainable public procurement on supplier management-The case of French public hospitals. Ind. Mark. Manag. 2012, 41, 573-580. [CrossRef]

55. Walker, H.; Brammer, S. The relationship between sustainable procurement and e-procurement in the public sector. Int. J. Prod. Econ. 2012, 140, 256-268. [CrossRef]

56. Webster, C.; Ivanov, S. Robotics, artificial intelligence, and the evolving nature of work. In Digital Transformation in Business and Society; Springer: Berlin/Heidelberg, Germany, 2020; pp. 127-143.

57. Wen, J.; He, L.; Zhu, F. Swarm robotics control and communications: Imminent challenges for next generation smart logistics. IEEE Commun. Mag. 2018, 56, 102-107. [CrossRef]

58. Merlino, M.; Sproge, I. The augmented supply chain. Procedia Eng. 2017, 178, 308-318. [CrossRef]

59. Crosby, M.; Pattanayak, P.; Verma, S.; Kalyanaraman, V. Blockchain technology: Beyond bitcoin. Appl. Innov. 2016,2 , 71.

60. Tian, F. An agri-food supply chain traceability system for China based on RFID blockchain technology. In Proceedings of the 2016 13th International Conference on Service Systems and Service Management (ICSSSM), Kunming, China, 24-26 June 2016; pp. 1-6.

61. Tian, F. A Supply Chain Traceability System for Food Safety Based on HACCP, Blockchain Internet Things. In Proceedings of the 2017 International Conference on Service Systems and Service Management, Dalian, China, 26-30 November 2017; pp. 1-6.

62. Abeyratne, S.A.; Monfared, R.P. Blockchain ready manufacturing supply chain using distributed ledger. Int. J. Res. Eng. Technol. 2016, 5, 1-10.

63. De Sousa Jabbour, A.B.L.; Chiappetta Jabbour, C.J.; Sarkis, J.; Gunasekaran, A.; Furlan Matos Alves, M.W.; Ribeiro, D.A. Decarbonisation of operations management-looking back, moving forward: A review and implications for the production research community. Int. J. Prod. Res. 2019, 57, 4743-4765. [CrossRef]

64. Oh, J.; Jeong, B. Tactical supply planning in smart manufacturing supply chain. Robotics Comput.-Integr. Manuf. 2019, 55, 217-233. [CrossRef]

65. Lee, I.; Lee, K. The Internet of Things (IoT): Applications, investments, and challenges for enterprises. Bus. Horiz. 2015, 58, 431-440. [CrossRef]

66. Zhong, H.; Nof, S.Y. The dynamic lines of collaboration model: Collaborative disruption response in cyber-physical systems. Comput. Ind. Eng. 2015, 87, 370-382. [CrossRef]

67. Esmaeilikia, M.; Fahimnia, B.; Sarkis, J.; Govindan, K.; Kumar, A.; Mo, J. Tactical supply chain planning models with inherent flexibility: Definition and review. Ann. Oper. Res. 2016, 244, 407-427. [CrossRef]

68. Korb, K.B.; Nicholson, A.E. Bayesian Artificial Intelligence; CRC Press: Boca Raton, FL, USA, 2010.

69. Pomerleau, D.A. Neural Network Perception for Mobile Robot Guidance; Springer Science \& Business Media: Berlin/Heidelberg, Germany, 2012; Volume 239.

70. Gaafar, L.K.; Choueiki, M.H. A neural network model for solving the lot-sizing problem. Omega 2000, 28, 175-184. [CrossRef]

71. Nissen, M.E.; Sengupta, K. Incorporating software agents into supply chains: Experimental investigation with a procurement task. Mis Q. 2006, 30, 145-166. [CrossRef]

72. Ciulla, G.; D'Amico, A.; Brano, V.L.; Traverso, M. Application of optimized artificial intelligence algorithm to evaluate the heating energy demand of non-residential buildings at European level. Energy 2019, 176, 380-391. [CrossRef]

73. Angerhofer, B.J.; Angelides, M.C. System Dynamics Modelling in Supply Chain Management: Research Review. In Proceedings of the 2000 Winter Simulation Conference Proceedings (Cat. No. 00CH37165), Orlando, FL, USA, 10-13 December 2000; pp. 342-351. 
74. Tukuta, M.; Saruchera, F. Challenges facing procurement professionals in developing economies: Unlocking value through professional international purchasing. J. Transp. Supply Chain Manag. 2015, 9, 1-9. [CrossRef]

75. Chou, J.-S.; Lin, C.-W.; Pham, A.-D.; Shao, J.-Y. Optimized artificial intelligence models for predicting project award price. Autom. Constr. 2015, 54, 106-115. [CrossRef]

76. Jie, Y.; Subramanian, N.; Ning, K.; Edwards, D. Product delivery service provider selection and customer satisfaction in the era of internet of things: A Chinese e-retailers' perspective. Int. J. Prod. Econ. 2015, 159, 104-116.

77. AlKhalifah, A.; Ansari, G.A. Modeling E-Procurement System through UML Using Data Mining Technique for Supplier Performance. In Proceedings of the 2016 International Conference on Software Networking (ICSN), Jeju, Korea, 23-26 May 2016; pp. 1-6.

78. Bag, S. Fuzzy VIKOR approach for selection of big data analyst in procurement management. J. Transp. Supply Chain Manag. 2016, 10, 1-6. [CrossRef]

79. Ellram, L.M.; Tate, W.L. The use of secondary data in purchasing and supply management (P/SM) research. J. Purch. Supply Manag. 2016, 22, 250-254. [CrossRef]

80. Fazekas, M.; Tóth, I.J.; King, L.P. An objective corruption risk index using public procurement data. Eur. J. Crim. Policy Res. 2016, 22, 369-397. [CrossRef]

81. Zhao-yang, B.; Ling-li, S.; Lin-jie, S. Vendor selection and order allocation in the locomotive manufacturing industry using cloud technology. Int. J. Simul. Syst. Sci. Technol. 2016, 17. [CrossRef]

82. Mladineo, M.; Veza, I.; Gjeldum, N. Solving partner selection problem in cyber-physical production networks using the HUMANT algorithm. Int. J. Prod. Res. 2017, 55, 2506-2521. [CrossRef]

83. Moretto, A.; Ronchi, S.; Patrucco, A.S. Increasing the effectiveness of procurement decisions: The value of big data in the procurement process. Int. J. RF Technol. 2017, 8, 79-103. [CrossRef]

84. Trappey, A.J.; Trappey, C.V.; Fan, C.-Y.; Hsu, A.P.; Li, X.-K.; Lee, I.J. IoT patent roadmap for smart logistic service provision in the context of Industry 4.0. J. Chin. Inst. Eng. 2017, 40, 593-602. [CrossRef]

85. You, L.; Yao, D.-Q.; Sikora, R.T.; Nag, B. An Adaptive Supplier Selection Mechanism in E-Procurement Marketplace. J. Int. Technol. Inf. Manag. 2017, 26, 94-116.

86. Abolbashari, M.H.; Chang, E.; Hussain, O.K.; Saberi, M. Smart buyer: A Bayesian network modelling approach for measuring and improving procurement performance in organisations. Knowl. Based Syst. 2018, 142, 127-148. [CrossRef]

87. Choi, Y.; Lee, H.; Irani, Z. Big data-driven fuzzy cognitive map for prioritising IT service procurement in the public sector. Ann. Oper. Res. 2018, 270, 75-104. [CrossRef]

88. Chopra, A. Technology in Procurement Supply as Prevalent Today Scope for Future. In Proceedings of the 2018 International Conference on Automation and Computational Engineering (ICACE), Dalian, China, 3-5 October 2018; pp. $216-223$.

89. Enayet, A.; Razzaque, M.A.; Hassan, M.M.; Alamri, A.; Fortino, G. A mobility-aware optimal resource allocation architecture for big data task execution on mobile cloud in smart cities. IEEE Commun. Mag. 2018, 56, 110-117. [CrossRef]

90. Jeong, S.; Na, W.; Kim, J.; Cho, S. Internet of Things for smart manufacturing system: Trust issues in resource allocation. IEEE Int. Things J. 2018, 5, 4418-4427. [CrossRef]

91. Kaur, H.; Singh, S.P. Heuristic modeling for sustainable procurement and logistics in a supply chain using big data. Comput. Oper. Res. 2018, 98, 301-321. [CrossRef]

92. Li, S.; Ni, Q.; Sun, Y.; Min, G.; Al-Rubaye, S. Energy-efficient resource allocation for industrial cyber-physical IoT systems in 5G era. IEEE Trans. Ind. Inform. 2018, 14, 2618-2628. [CrossRef]

93. Lin, S.; Laili, Y.; Luo, Y. Integrated Optimization Supplier SELECTION service Scheduling in Cloud Manufacturing Environment. In Proceedings of the 2018 4th International Conference on Universal Village (UV), Boston, MA, USA, 23-24 October 2018; pp. $1-6$.

94. Macrinici, D.; Cartofeanu, C.; Gao, S. Smart contract applications within blockchain technology: A systematic mapping study. Telemat. Inform. 2018, 35, 2337-2354. [CrossRef]

95. Nicoletti, B. The future: Procurement 4.0. In Agile Procurement; Springer: Berlin/Heidelberg, Germany, $2018 ;$ pp. 189-230.

96. Pinochet, L.H.C.; Lopes, E.L.; Srulzon, C.H.F.; Onusic, L.M. The influence of the attributes of “Internet of Things" products on functional and emotional experiences of purchase intention. Innov. Manag. Rev. 2018, 15, 3. [CrossRef]

97. Singh, A.; Kumari, S.; Malekpoor, H.; Mishra, N. Big data cloud computing framework for low carbon supplier selection in the beef supply chain. J. Clean. Prod. 2018, 202, 139-149. [CrossRef]

98. Song, Q.; Zheng, Y.-J.; Huang, Y.-J.; Xu, Z.-G.; Sheng, W.-G.; Yang, J. Emergency drug procurement planning based on big-data driven morbidity prediction. IEEE Trans. Ind. Inf. 2018, 15, 6379-6388. [CrossRef]

99. Sun, W.; Liu, J.; Yue, Y.; Zhang, H. Double auction-based resource allocation for mobile edge computing in industrial internet of things. IEEE Trans. Ind. Inform. 2018, 14, 4692-4701. [CrossRef]

100. Tönnissen, S.; Teuteberg, F. Using Blockchain Technology for Business Processes in Purchasing-Concept case Study-Based Evidence. In Proceedings of the International Conference on Business Information Systems, Colorado Springs, CO, USA, 8-10 June 2018; pp. 253-264.

101. Uygun, Y.; Ilie, M. Autonomous manufacturing-related procurement in the era of industry 4.0. In Digitalisierung Im Einkauf; Springer: Berlin/Heidelberg, Germany, 2018; pp. 81-97. 
102. Wang, H.; Song, Y.; Tu, S.; Li, Y. The Selection Logist. Suppliers under Cloud Manuf. In Proceedings of the 2018 2nd International Conference on Artificial Intelligence: Technologies and Applications (ICAITA 2018), Chengdu, China, 25-26 March 2018; pp. 183-185.

103. Wang, L.; Guo, S.; Li, X.; Du, B.; Xu, W. Distributed manufacturing resource selection strategy in cloud manufacturing. Int. J. Adv. Manuf. Technol. 2018, 94, 3375-3388. [CrossRef]

104. Yin, L.; Luo, J.; Luo, H. Tasks scheduling and resource allocation in fog computing based on containers for smart manufacturing. IEEE Trans. Ind. Inform. 2018, 14, 4712-4721. [CrossRef]

105. Zhou, Y.; Yu, F.R.; Chen, J.; Kuo, Y. Robust energy-efficient resource allocation for IoT-powered cyber-physical-social smart systems with virtualization. IEEE Internet Things J. 2018, 6, 2413-2426. [CrossRef]

106. Afrin, M.; Jin, J.; Rahman, A.; Tian, Y.-C.; Kulkarni, A. Multi-objective resource allocation for Edge Cloud based robotic workflow in smart factory. Future Gener. Comput. Syst. 2019, 97, 119-130. [CrossRef]

107. Berru, Y.T.; Batista, V.F.L.; Torres-Carrión, P.; Jimenez, M.G. Artificial Intelligence Techniques to Detect Prevent Corruption in Procurement: A Systematic Literature Rev. In Proceedings of the International Conference on Applied Technologies, Latacunga Canton, Ecuador, 4-6 December 2019; pp. 254-268.

108. Çalı, S.; Balaman, Ş.Y. Improved decisions for marketing, supply and purchasing: Mining big data through an integration of sentiment analysis and intuitionistic fuzzy multi criteria assessment. Comput. Ind. Eng. 2019, 129, 315-332. [CrossRef]

109. Cavalcante, I.M.; Frazzon, E.M.; Forcellini, F.A.; Ivanov, D. A supervised machine learning approach to data-driven simulation of resilient supplier selection in digital manufacturing. Int. J. Inf. Manag. 2019, 49, 86-97. [CrossRef]

110. Chang, S.E.; Chen, Y.-C.; Lu, M.-F. Supply chain re-engineering using blockchain technology: A case of smart contract based tracking process. Technol. Forecast. Soc. Chang. 2019, 144, 1-11. [CrossRef]

111. Gavrilova, J.A.; Kvitsinia, N.V.; Kalashnikova, N.A. Development the Institute Public Procurement in Modern Russia: Between Blockchain Administration. In Proceedings of the Competitive Russia: Foresight Model of Economic and Legal Development in the Digital Age, Volgograd, Russia, 19-20 September 2019; Springer: Berlin/Heidelberg, Germany, 2019; pp. 388-394.

112. Jordon, K.; Dossou, P.-E.; Junior, J.C. Using lean manufacturing and machine learning for improving medicines procurement and dispatching in a hospital. Procedia Manuf. 2019, 38, 1034-1041. [CrossRef]

113. Lamba, K.; Singh, S.P. Dynamic supplier selection and lot-sizing problem considering carbon emissions in a big data environment. Technol. Forecast. Soc. Chang. 2019, 144, 573-584. [CrossRef]

114. Layaq, M.W.; Goudz, A.; Noche, B.; Atif, M. The impact of digitization on tactical procurement and its risks management. Int. Acad. J. Procure. Supply Chain Manag. 2019, 3, 217-234.

115. Li, Y.; Yang, W.; He, P.; Chen, C.; Wang, X. Design and management of a distributed hybrid energy system through smart contract and blockchain. Appl. Energy 2019, 248, 390-405. [CrossRef]

116. Muñoz-Garcia, C.; Vila, J. Value creation in the international public procurement market: In search of springbok firms. J. Bus. Res. 2019, 101, 516-521. [CrossRef]

117. Rane, S.B.; Thakker, S.V. Green procurement process model based on blockchain-IoT integrated architecture for a sustainable business. Manag. Environ. Qual. Int. J. 2019, 31, 3. [CrossRef]

118. Sachdeva, N.; Shrivastava, A.K.; Chauhan, A. Modeling supplier selection in the era of Industry 4.0. Benchmarking An Int. J. 2019, 28, 5. [CrossRef]

119. Srai, J.S.; Lorentz, H. Developing design principles for the digitalisation of purchasing and supply management. J. Purch. Supply Manag. 2019, 25, 78-98. [CrossRef]

120. Akaba, T.I.; Norta, A.; Udokwu, C.; Draheim, D. A Framework for the Adoption Blockchain-Based e-Procurement Systems in the Public Sector. In Proceedings of the Conference on e-Business, e-Services and e-Society, Skukuza, South Africa, 6-8 April 2020; pp. 3-14.

121. Bag, S.; Wood, L.C.; Mangla, S.K.; Luthra, S. Procurement 4.0 and its implications on business process performance in a circular economy. Resour. Conserv. Recycl. 2020, 152, 104502. [CrossRef]

122. Chen, Z.; Ming, X.; Zhou, T.; Chang, Y. Sustainable supplier selection for smart supply chain considering internal and external uncertainty: An integrated rough-fuzzy approach. Appl. Soft Comput. 2020, 87, 106004. [CrossRef]

123. Gholizadeh, H.; Fazlollahtabar, H.; Khalilzadeh, M. A robust fuzzy stochastic programming for sustainable procurement and logistics under hybrid uncertainty using big data. J. Clean. Prod. 2020, 258, 120640. [CrossRef]

124. Ghosh, D.; Sant, T.G.; Kuiti, M.R.; Swami, S.; Shankar, R. Strategic decisions, competition and cost-sharing contract under industry 4.0 and environmental considerations. Resour. Conserv. Recycl. 2020, 162, 105057. [CrossRef]

125. Gupta, R.; Tanwar, S.; Al-Turjman, F.; Italiya, P.; Nauman, A.; Kim, S.W. Smart contract privacy protection using ai in cyberphysical systems: Tools, techniques and challenges. IEEE Access 2020, 8, 24746-24772. [CrossRef]

126. Legenvre, H.; Henke, M.; Ruile, H. Making sense of the impact of the internet of things on Purchasing and Supply Management: A tension perspective. J. Purch. Supply Manag. 2020, 26, 100596. [CrossRef]

127. Nandankar, S.; Sachan, A. Electronic procurement adoption, usage and performance: A literature review. J. Sci. Technol. Policy Manag. 2020, 11, 4. [CrossRef]

128. Nicoletti, B. Procurement 4.0 and the Fourth Industrial Revolution; Springer Nature: Berlin/Heidelberg, Germany, 2020.

129. Pu, Z.; Jiang, Q.; Yue, H.; Tsaptsinos, M. Agent-based supply chain allocation model and its application in smart manufacturing enterprises. J. Supercomput. 2020, 76, 3188-3198. [CrossRef] 
130. Schulze-Horn, I.; Hueren, S.; Scheffler, P.; Schiele, H. Artificial Intelligence in Purchasing: Facilitating Mechanism Design-based Negotiations. Appl. Artif. Intell. 2020, 34, 618-642. [CrossRef]

131. Zhang, G.; Chen, C.-H.; Zheng, P.; Zhong, R.Y. An integrated framework for active discovery and optimal allocation of smart manufacturing services. J. Clean. Prod. 2020, 273, 123144. [CrossRef]

132. Kaur, H.; Singh, S.P. Multi-stage hybrid model for supplier selection and order allocation considering disruption risks and disruptive technologies. Int. J. Prod. Econ. 2021, 231, 107830. [CrossRef]

133. Ghosh, P.K.; Manna, A.K.; Dey, J.K.; Kar, S. Supply chain coordination model for green product with different payment strategies: A game theoretic approach. J. Clean. Prod. 2021, 290, 125734. [CrossRef]

134. Ramirez-Peña, M.; Sotano, A.J.S.; Pérez-Fernandez, V.; Abad, F.J.; Batista, M. Achieving a sustainable shipbuilding supply chain under I4. 0 perspective. J. Clean. Prod. 2020, 244, 118789. [CrossRef]

135. de Arroyabe, J.F.; Arranz, N.; Schumann, M.; Arroyabe, M.F. The development of CE business models in firms: The role of circular economy capabilities. Technovation 2021, 106, 102292. [CrossRef]

136. Geng, Y.; Sarkis, J.; Bleischwitz, R. How to Globalize the Circular Economy; Nature Publishing Group: Berlin/Heidelberg, Germany, 2019.

137. Nagy, J.; Oláh, J.; Erdei, E.; Máté, D.; Popp, J. The role and impact of Industry 4.0 and the internet of things on the business strategy of the value chain-The case of Hungary. Sustainability 2018, 10, 3491. [CrossRef]

138. Kersten, W.; Blecker, T.; Ringle, C.M. Digitalization in Supply Chain Management and Logistics: Smart and Digital Solutions for an Industry 4.0 Environment; Epubli GmbH: Berlin, Germany, 2017.

139. Porter, M.E.; Porter, M.E. The Competitive Advantage of Nations: With a New Introduction; Harvard Business Publishing: Brighton, MA, USA, 1998.

140. Núñez-Merino, M.; Maqueira-Marín, J.M.; Moyano-Fuentes, J.; Martínez-Jurado, P.J. Information and digital technologies of Industry 4.0 and Lean supply chain management: A systematic literature review. Int. J. Prod. Res. 2020, 58, 5034-5061. [CrossRef]

141. Ivanov, D.; Dolgui, A.; Sokolov, B. The impact of digital technology and Industry 4.0 on the ripple effect and supply chain risk analytics. Int. J. Prod. Res. 2019, 57, 829-846. [CrossRef]

142. Babiceanu, R.F.; Seker, R. Big Data and virtualization for manufacturing cyber-physical systems: A survey of the current status and future outlook. Comput. Ind. 2016, 81, 128-137. [CrossRef]

143. Fatorachian, H.; Kazemi, H. Impact of Industry 4.0 on supply chain performance. Prod. Plan. Control 2021, 32, 63-81. [CrossRef]

144. Jerome, J.J.J.; Saxena, D.; Sonwaney, V.; Foropon, C. Procurement 4.0 to the rescue: Catalysing its adoption by modelling the challenges. Benchmarking Int. J. 2021. [CrossRef]

145. Bag, S.; Dhamija, P.; Gupta, S.; Sivarajah, U. Examining the role of procurement 4.0 towards remanufacturing operations and circular economy. Prod. Plan. Control 2020, 1-16. [CrossRef]

146. Golpîra, H.; Khan, S.A.R.; Safaeipour, S. A review of logistics internet-of-things: Current trends and scope for future research. J. Ind. Inf. Integr. 2021, 22, 100194.

147. Tirkolaee, E.B.; Sadeghi, S.; Mooseloo, F.M.; Vandchali, H.R.; Aeini, S. Application of Machine Learning in Supply Chain Management: A Comprehensive Overview of the Main Areas. Math. Prob. Eng. 2021. [CrossRef]

148. Attari, M.Y.N.; Torkayesh, A.E. Developing benders decomposition algorithm for a green supply chain network of mine industry: Case of Iranian mine industry. Oper. Res. Perspect. 2018, 5, 371-382. [CrossRef]

149. Yazdani, M.; Torkayesh, A.E.; Stević, Ž.; Chatterjee, P.; Ahari, S.A.; Hernandez, V.D. An Interval Valued Neutrosophic DecisionMaking Structure for Sustainable Supplier Selection. Expert. Syst. Appl. 2021, 183, 115354. [CrossRef]

150. Vandchali, H.R.; Cahoon, S.; Chen, S.L. The impact of supply chain network structure on relationship management strategies: An empirical investigation of sustainability practices in retailers. Sustain. Prod. Consum. 2021, 28, 281-299. [CrossRef]

151. Khakbaz, A.; Tirkolaee, E.B. A sustainable hybrid manufacturing/remanufacturing system with two-way substitution and WEEE directive under different market conditions. Optimization 2021. [CrossRef] 